The Impact of the Dodd-Frank Act on Small Business

Michael D. Bordo and J ohn V. Duca

Federal Reserve Bank of Dallas Research Department Working Paper 1806 https://doi.org/10.24149/wp1806 


\title{
The Impact of the Dodd-Frank Act on Small Business*
}

\author{
Michael D. Bordo \\ Rutgers University \\ National Bureau of Economic Research \\ Hoover Institution, Stanford University \\ bordo@econ.rutgers.edu
}

\begin{abstract}
John V. Duca*
Oberlin College, Dept. of Economics, 223 Rice Hall, Oberlin, OH 44074, jduca@oberlin.edu

Research Department, Federal Reserve Bank of Dallas, P.O. Box 655906, Dallas, TX 75265, john.v.duca@dal.frb.org
\end{abstract}

April 21, 2018

\begin{abstract}
There are concerns that the Dodd-Frank Act (DFA) has impeded small-business lending. By increasing the fixed regulatory compliance requirements needed to make business loans and operate a bank, the DFA disproportionately reduced the incentives for all banks to make very modest loans and reduced the viability of small banks, whose small-business share of commercial and industrial (C\&I) loans is generally much higher than that of larger banks. Despite an economic recovery, the small-loan share of C\&I loans at large banks and banks with \$300 or more million in assets has fallen 9 percentage points since the DFA was passed in 2010, with the magnitude of the decline twice as large at small banks. Controlling for cyclical effects and bank size, we find that these declines in the small-loan share of C\&I loans are almost all statistically attributed to the change in regulatory regime. Examining Federal Reserve survey data, we find evidence that the DFA prompted a relative tightening of bank credit standards on C\&I loans to small versus large firms, consistent with the DFA inducing a decline in small-business lending through loan supply effects. We also empirically model the pace of business formation, finding that it had downshifted around the time when the DFA and the Sarbanes-Oxley Act were announced. Timing patterns suggest that business formation has more recently ticked higher, coinciding with efforts to provide regulatory relief to smaller banks via modifying rules implementing the DFA. The upturn contrasts with the impact of the Sarbanes-Oxley Act, which appears to persistently restrain business formation.
\end{abstract}

Keywords: small-business lending, business formation, regulation, Dodd-Frank, Sarbanes-Oxley, secular stagnation

JEL Codes: E40, E50, G21

\footnotetext{
* We thank Mark Bils, Iftekhar Hasan, Kose John, Pete Klenow, Monika Piazzesi, Ned Prescott, Martin Schneider, John Taylor, Lena Tonzer, Kevin Warsh, Michael Weiss, and seminar participants at the Stanford Macroeconomics Faculty Lunch and the $201726^{\text {th }}$ Annual Rome International Conference on Money, Banking, and Finance for suggestions. We thank Kelsey Reichow for sharing data on small-sized business loans. We also thank Tyler Atkinson, Daniel Chapman, and Valerie Grossman for providing excellent research assistance, as well as Jim Carlson and John Genovese for providing excellent IT support. The views expressed are those of the authors and do not necessarily reflect the views of the Federal Reserve Bank of Dallas or the Federal Reserve System. Any remaining errors are those of the authors.
} 
The Dodd Frank Act of 2010 (DFA) was designed to overcome the sources of excessive leverage and systemic risk in the U.S. financial sector perceived to have created the Great Financial Crisis of 2007-2008. Since then considerable controversy has swirled over the efficacy of various components of the multi-faceted Act. Many have been critical of the Volcker Rule, others have praised the elevation of capital ratios and the requirements for banks to undergo periodic stress tests. However there has been mounting concern in the financial community, the Congress and the press over the negative impact of the DFA regulations on small banks and businesses. One such concern is that the DFA has unduly impeded small-business lending, and thereby may have impeded the pace of business formation, which has been unusually slow in recent years (e.g., see Decker, et al., 2016 and Figure 1). By increasing the fixed regulatory compliance requirements ${ }^{1}$ for making business loans and operating a bank, the DFA has disproportionately reduced the incentives of all banks to make very small loans and reduced the viability of lesser-sized banks, whose small business share of commercial and industrial (C\&I) loans is generally much higher than that of larger banks (see Dahl et al., 2016; Lux and Greene, 2015, and Reichow, 2017). C\&I loans to small firms relative to others may also decline to the extent that stress tests tend to apply higher risk assessments on loans to small or new firms, consistent with the arguments and evidence in Covas (2017). ${ }^{2}$ It has been argued that through these intensive and extensive margin effects, the DFA has impeded small business lending during the recovery from the Great Recession.

Indeed, despite an economic recovery, the share of C\&I loans under \$1 million in size at banks with $\$ 300$ million or more in assets has plunged since the DFA was passed in 2010 (Figure 2). Driving this development was a decline in 2011 in the real aggregate volume of C\&I loans

\footnotetext{
${ }^{1}$ For example, increased documentation and recorded ratings of each loan, especially at stress-tested banks.

${ }^{2}$ It is beyond the scope of this study to assess whether new risk assessments are optimal in obtaining benefits from lowering bank failure risk versus incurring indirect costs in the form of negative externalities from lowering competition from—and entry by—small firms whose access to bank credit may have been reduced.
} 


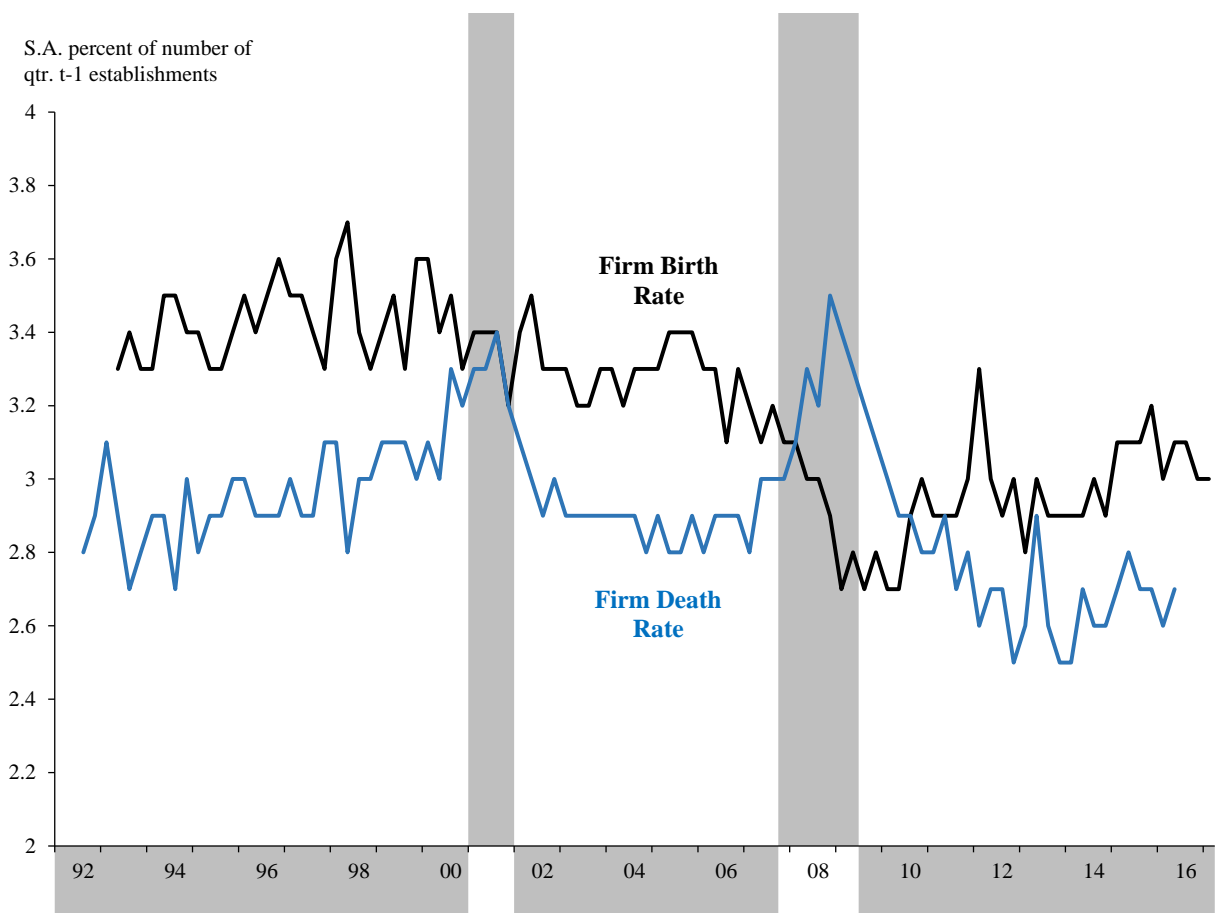

Figure 1: Despite an Economic Recovery, New Business Formation Was Below Its Pre-Recession (2002-07) Pace Until Late 2014. Source: U.S. Bureau of Labor Statistics.

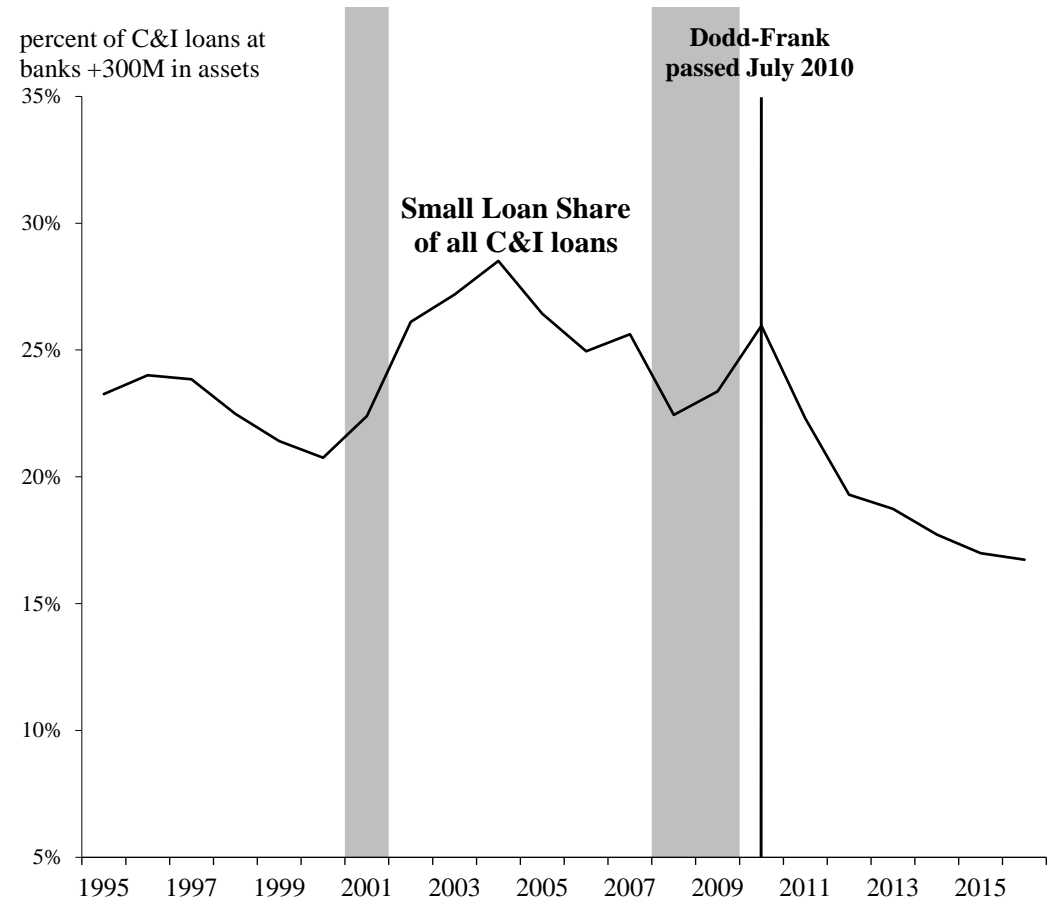

Figure 2: The Small Loan Share of C\&I loans After the Dodd-Frank Act Passes

Sources: Consolidated Reports of Condition and Income, Federal Financial Institutions Examination Council, and authors' calculations. Shares at banks with assets of at least \$300 million—consistently available from 1993-2016. Shaded areas are recessions. 
under \$1 million in size and a sluggish and only partial unwinding by 2016. This contrasts with an 80 percent rise in the real aggregate volume of loans over \$1 million in size since 2010. This is not an artifact of inflation or nominal GDP growth that caused a migration of loans between the size categories as formal robustness checks later demonstrate and as illustrated in Figure 3 by a sharp break in the relative trends in the two series since 2010. Indeed, between 1993 and 2010, the small and large size real loan series trended together and had risen by roughly similar amounts: 79 and 67 percent, respectively.

These patterns also occurred at large banks, where the small loan share of C\&I loans (Figure 4) posted declines similar to those in Figure 2, but which cannot be attributed to pre-DFA trends in the consolidation of the banking system away from small bank. Using annual data

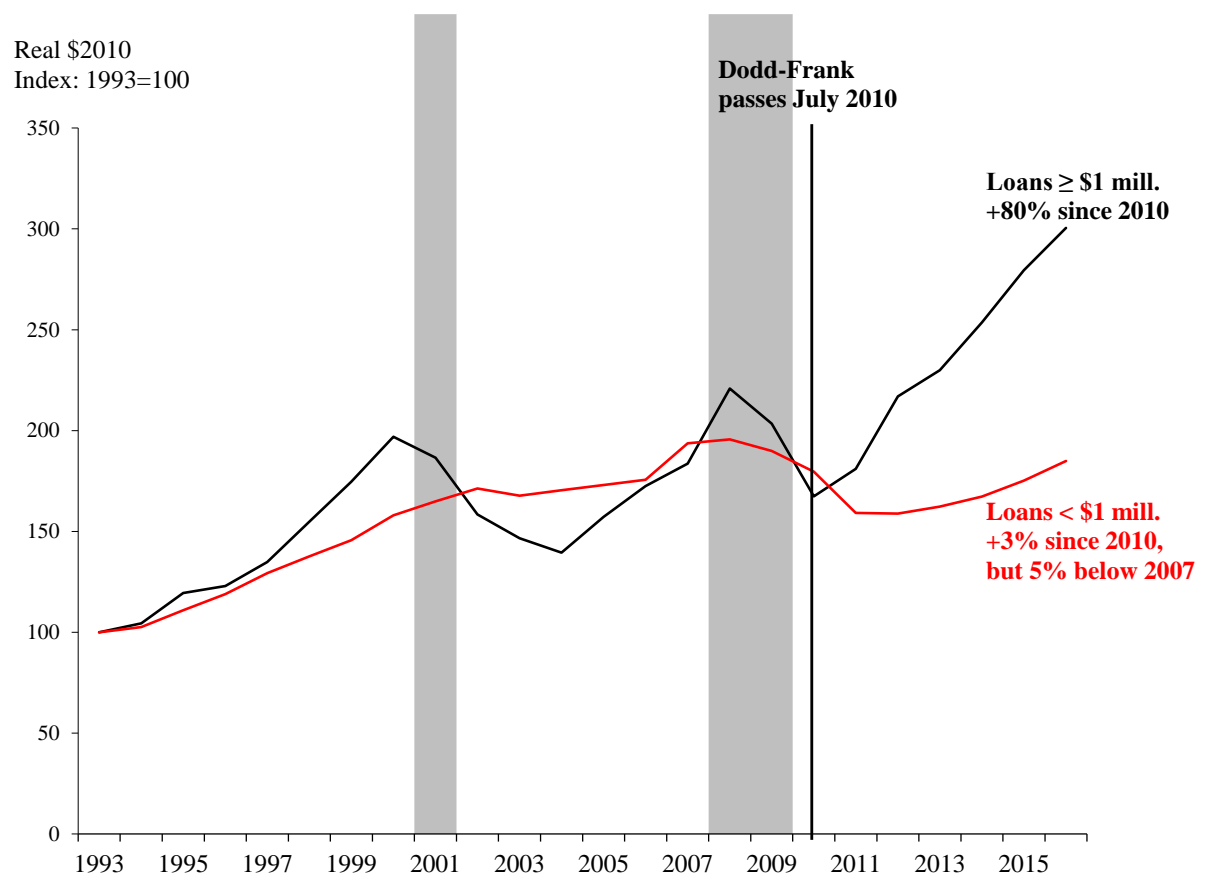

Figure 3: Small C\&I Loans Trend Differently from Large Loans Since Dodd Frank is Passed

Sources: Bureau of Economic Advisors, Consolidated Reports of Condition and Income, Federal Financial Institutions Examination Council, and authors' calculations. Aggregate real loans at banks with assets of at least \$300 millionconsistently available from 1993-2016 and deflated with the implicit GDP price deflator. Shaded areas are recessions. 


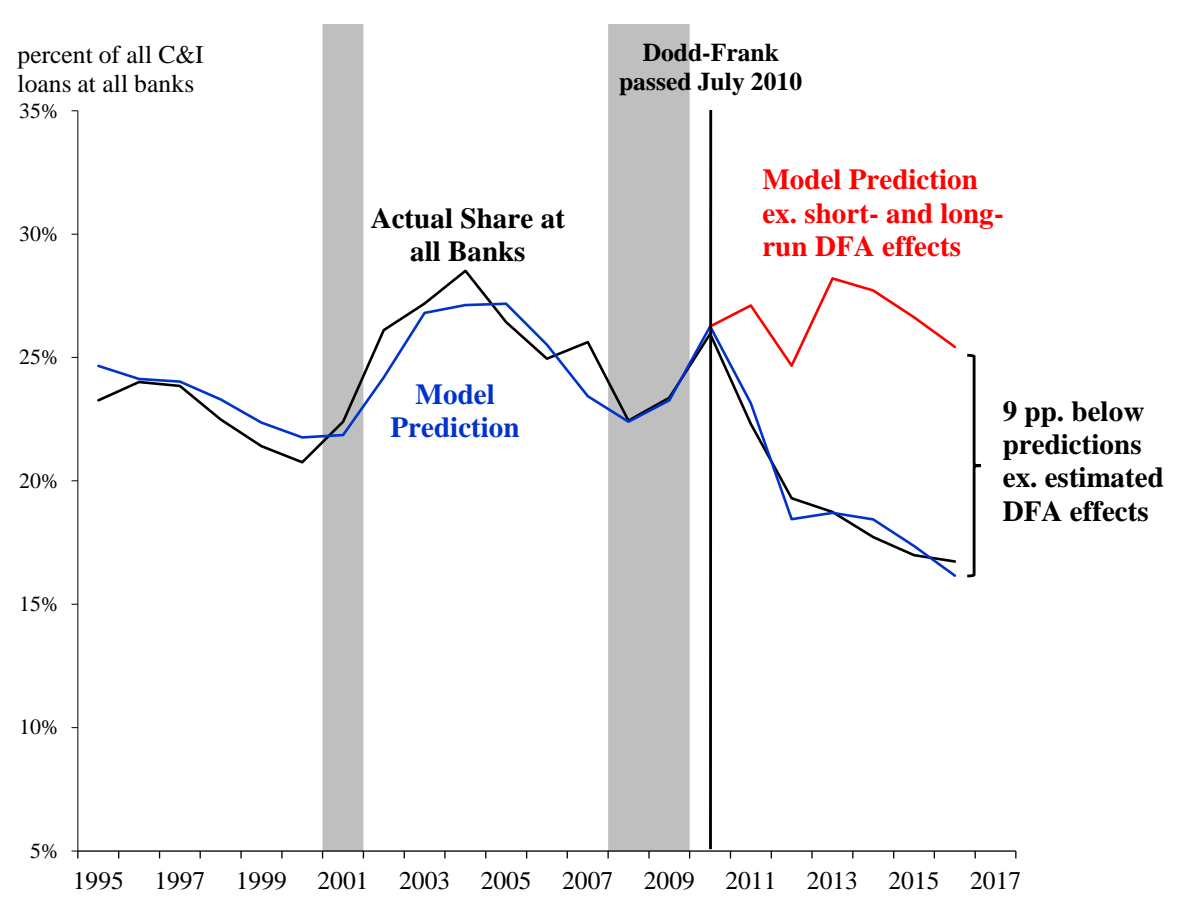

Figure 4: The Small Loan Share of C\&I loans Falls At Large Banks After Dodd-Frank

Sources: Consolidated Reports of Condition and Income, Federal Financial Institutions Examination Council, and authors' calculations. Shares at banks with assets in the top $88^{\text {th }}-100$ top percentiles. Shaded areas are recessions.

available since 1993 (described in Section II), we find that the bulk of the post-2010 declines (9 percentage points) at both categories of banks cannot be attributed to business cycle effects or shifts in bank funding cost spreads and appear to have arisen from regulatory reforms enacted since DFA's passage. The estimated magnitude of this regime effect is about twice as much (18 percentage points) for smaller banks. These results shown in Section II are consistent with concerns that an unintended consequence of the DFA has been to reduce small business lending.

To further assess whether these loan patterns do not simply reflect loan demand shifts that coincided with the DFA, Section III examines bank loan officer survey data on changes in credit standards to assess whether the DFA has induced loan supply shifts away from small business lending. Bank survey results (Figure 5) indicate that bank credit standards for making C\&I loans became relatively tighter for small businesses compared with medium- and large-sized firms 


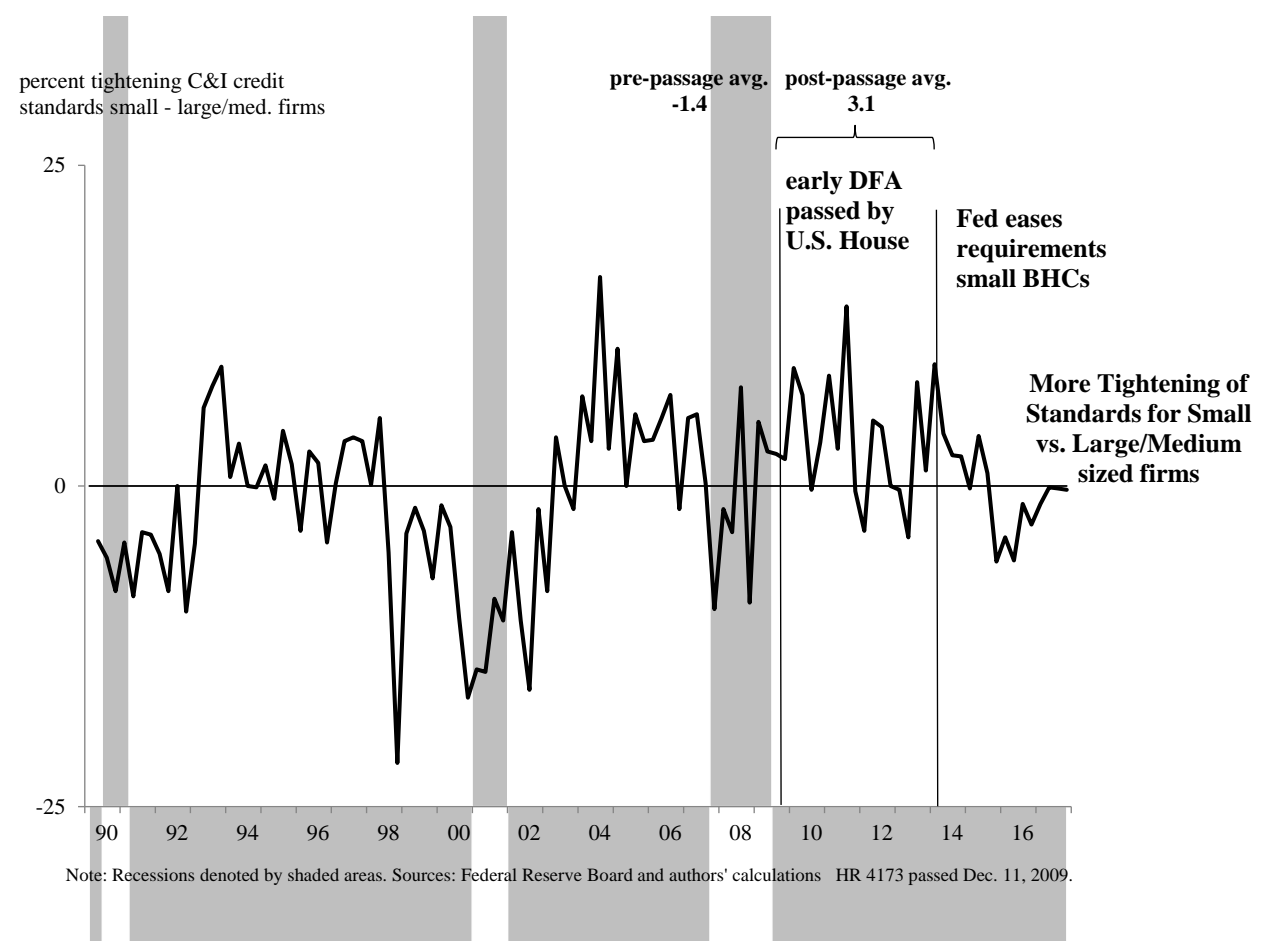

Figure 5: Share Banks Tightening Credit Standards on C\&I Loans to Small Firms Minus Share Tightening Credit Standards on Loans to Medium- and Large-Sized Firms.

Sources: Federal Reserve Board and authors’ calculations.

during the period when DFA requirements were most onerous on smaller banking organizations.

As shown in Figure 6, those survey data are consistent with the share of small businesses reporting to the National Federation of Independent Businesses (NFIB) that availability of credit had tightened in the prior three months. ${ }^{3}$ Furthermore, lending survey data suggest that regulatory relief for smaller banking organizations in 2015 may have helped stop a further deterioration of loan supply for small relative to large firms, but has not reversed earlier relative declines induced by the DFA. Section IV then assesses whether regulatory steps-namely, the DFA and the Sarbanes-Oxley Act of 2002 (SOX)—have played a role in slowing business formation. The last section of the paper provides perspective on our findings.

\footnotetext{
${ }^{3}$ NFIB data may reflect survivorship bias as there has been some downtrend in the number of survey respondents.
} 


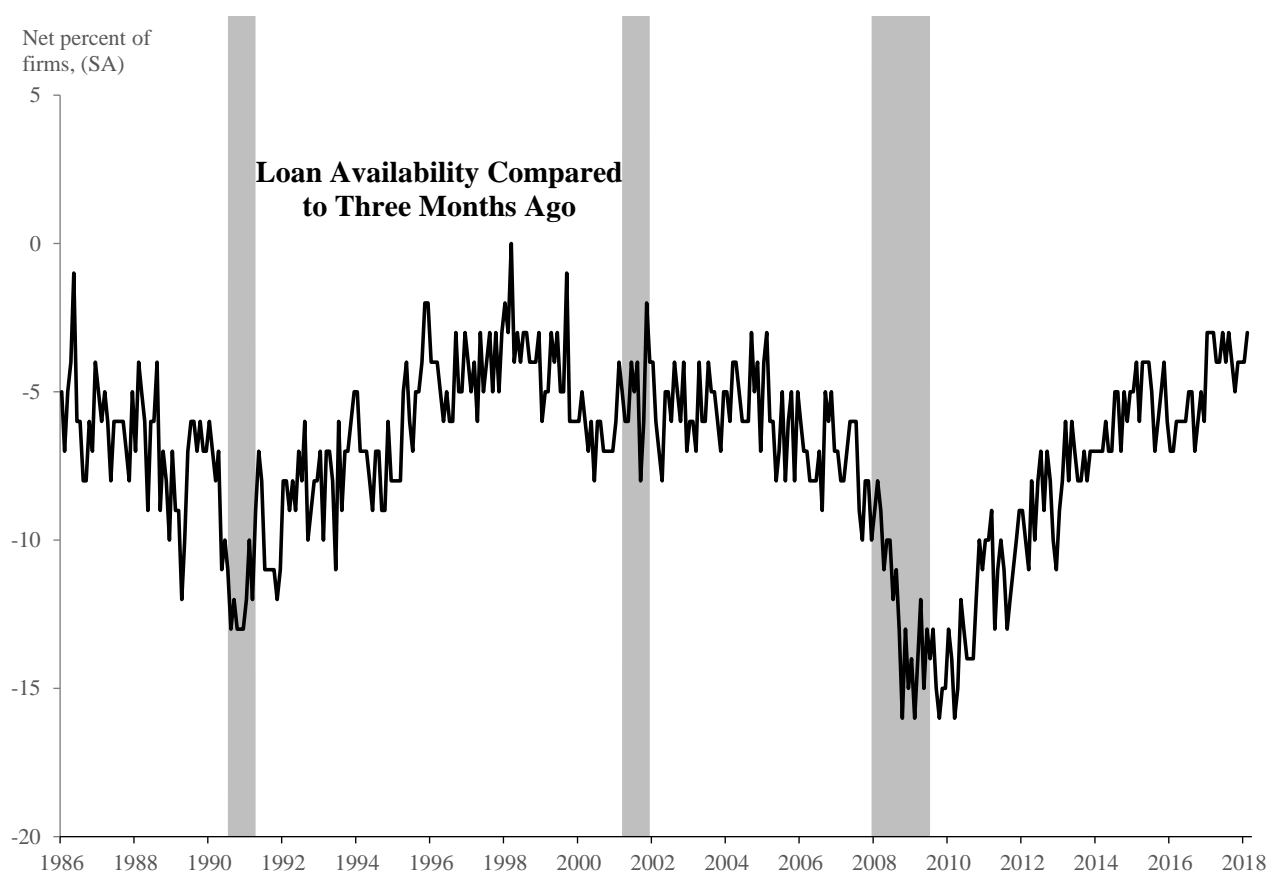

Figure 6: Loan Availability for Small Businesses Unusually Weak in the Great Recession and the Recovery from it.

Source: National Federation of Independent Businesses (NFIB). Net percent of firms seeing loans more minus less available than three months earlier for firms borrowing at least once every three months. Recessions are shaded.

\section{Data and Model Specifications for Analyzing the Small Business Share of C\&I Loans}

To limit complications from omitting factors that affect business lending in general, we focus on modeling the small business share of C\&I loans (SBShare, henceforth, referred to as "the small business loan share”), defined as the percent of domestic C\&I loans that are under \$1 million and outstanding. This ratio effectively eliminates common factors that roughly have equal proportional influences on small and all C\&I loans. The data are available from the June 30 Call Reports (Consolidated Reports of Condition and Income, Federal Financial Institutions Examination Council) from 1993 to 2017, and allow us to measure the small loan size share midway through each year. Owing to changes in reporting requirements on small banks, we consistently track the small loan size share for three categories of banks. ${ }^{4}$ For 1993-2016, we can track the small loan share

\footnotetext{
${ }^{4}$ There are two breaks in the data collection that need to be taken into account. First, after 2001, banks with assets under \$300 million were no longer required to report data on small loans, which would impart a spurious downward
} 
at banks with at least $\$ 300$ million in total assets (SBSHAll) and for banks with assets between \$300 million and \$1 billion (SBSHSmall). Because both of these measures are based on nominal asset size cutoffs and small banks tend to make a higher share of small-sized business loans, inflation and ongoing mergers—particularly among small banks—could impart an upward trend to these measures. To limit such distortions, we construct annual data on the small loan share at banks whose total assets are in the top 12 percent of banks in each year (SBSHLarge). This relative size cutoff translates into banks having at least $\$ 1$ billion in assets in 2016, and covers banks with least \$300 million in assets in prior years. This combination allows us to track SBSHLarge from 1993-2017 and limits the impact of banks migrating into a large-size category if a fixed nominal asset cutoff were applied to each year.

As shown in Figure 7, the three small loan share series generally move together, but with the small loan share notably higher at small versus the large size banks. Each series moves within a flat range from 1993 through 2010, but then shifts downward over several years to a notably lower range. Using the available full samples for small (1993-2016), all (1993-2016) and large (1993-2017) banks, unit root tests reject stationarity, finding evidence of a unit root in each series. This evidence is consistent with the view that the tougher regulatory regime instituted under DFA has discouraged banks from making small sized loans as argued by Covas (2017), Dahl et al. (2016), and Reichow (2017). Because the loan shares are based on outstanding loans, loan contracts are typically multi-year, and it took several years for the relevant agencies to draft precise regulations, the transition of the three loan share variables to the new regime would likely be drawn out as reflected in Figure 7. In addition, the DFA plausibly has a prolonged effect on entry and

time trend to the aggregate share if ignored. The second started in 2017, when banks with under $\$ 1$ billion were no longer required to distinguish between small sized foreign and domestic C\&I loans, while still being required to distinguish between total foreign and domestic C\&I loans. If ignored, the small loan size share would have a spurious jump in 2017 when foreign C\&I loans would be included in the numerator but not the denominator. 


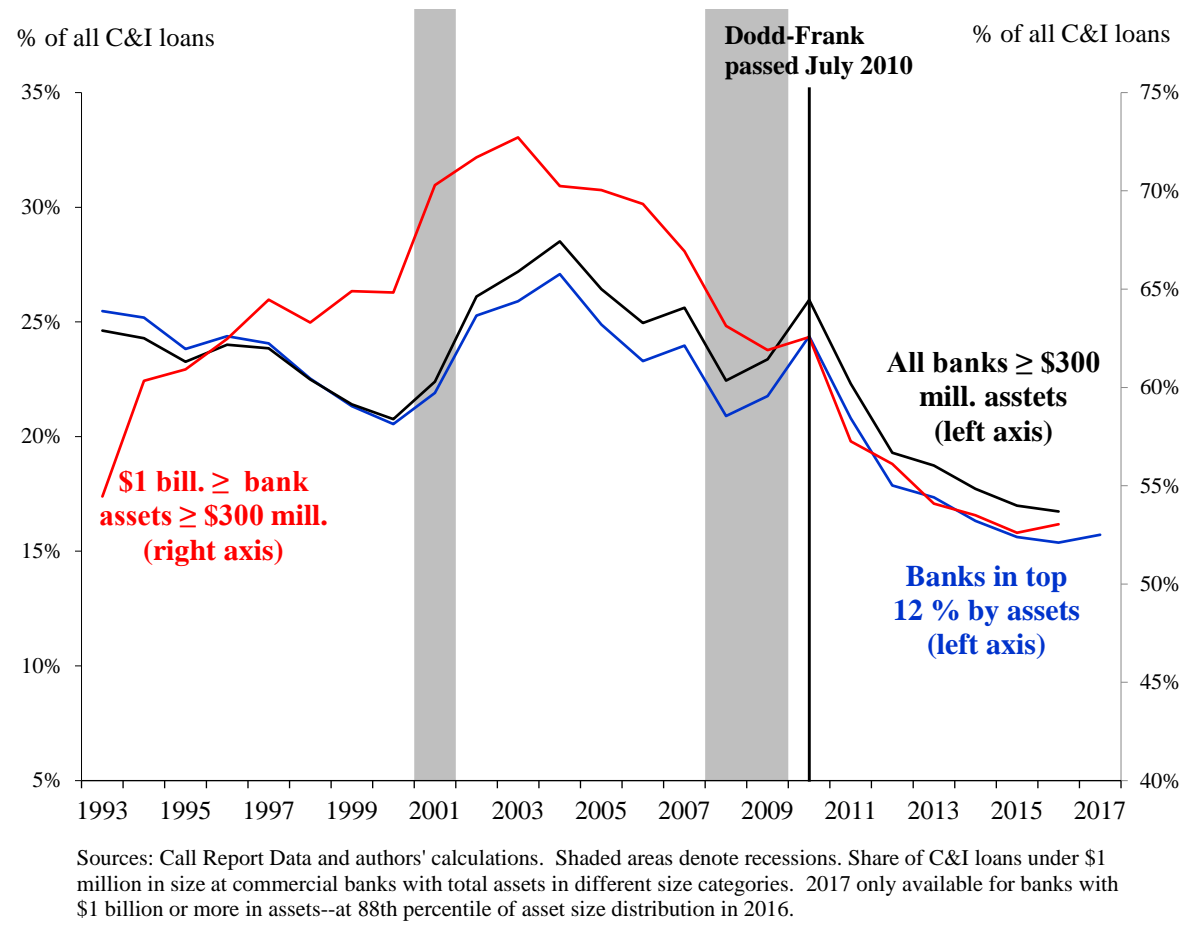

Figure 7: The Small Loan Share of C\&I loans Falls After the Dodd-Frank Act

Sources: Consolidated Reports of Condition and Income, Federal Financial Institutions Examination Council, and authors' calculations. Shares at all banks are for those with assets above $\$ 300$ million, small banks are at least as big but have assets below $\$ 1$ billion throughout the sample. Large banks have assets in the top $88^{\text {th }}-100$ percentiles for each year. Shaded areas are recessions.

exit into banking, as suggested by the sharp downshift in the number of new bank charters, from an annual range of 60 to 270 from 1990 to 2008, to about 0 since 2011.

In light of these data patterns, we use cointegration techniques to assess if the DFA regulatory regime has had both long-run and transition (short-run) effects on the small loan size share for each of the three asset categories of banks. We define the new regime with the variable DFASB, which equals 0 before 2010, $1 / 2$ in 2010, and 1 thereafter. Although DFA was passed after the mid-year 2010 Call Report (from which the small loan share readings for that year are 
constructed), banks likely had a good idea of the basic features of the legislation earlier that year. Reflecting some anticipatory effects, DFASB takes a value of $1 / 2$ in $2010 .^{5}$

To control for business and financial cycle influences we include two variables: the t-1 annual GDP output gap from CBO (OutputGap) and the t-1 annual average spread between the three-month dollar Libor and Treasury bill rates (LiborSP). ${ }^{6}$ These stationary variables help control for any cyclical influences that may affect the relative volumes of small versus larger C\&I loans. A higher Libor spread may reflect greater risk in the banking system and less willingness by banks to undertake risk in lending, consistent with loan supply evidence from Aron et al. (2010) and Bordo et al. (2016). Because small size loans are more typically made to smaller firms that are statistically less apt to survive, a higher Libor spread is likely to be associated with tougher loan supply conditions for small loans. For this reason we expect LiborSP to have a negative shortrun effect. The sign on OutputGap reflects two countervailing influences. If small firms are more apt to fail in recessions, one would expect OutputGap to have a positive sign from loan supply influences. On the other hand, OutputGap could have a negative sign if small firms need less temporary lending to survive in booms or if large firms borrow more to fund desired inventory accumulation in booms. In our error-correction framework, we found that alternative financial friction variables, such as spreads between corporate and Treasury bond yields, were insignificant, ostensibly as they are less bank centric than the Libor spread. We also found that alternative business cycle indicators, such as Treasury yield curve spreads and changes in the unemployment rate, were statistically insignificant.

\footnotetext{
${ }^{5}$ In other regressions not shown, this definition outperformed alternative definitions in which DFASB equaled 0 in 2010 and 1 thereafter, or 1 since 2010 or 1 since 2009. Note that the models using the paper's definition of DFASB attribute the 2010 rise in loan shares to cyclical factors following the Great Recession.

${ }^{6}$ Owing to the mid-year timing of the loan share series, the t- 1 annual data on these variables translate into effects from the $\mathrm{t}-2$ quarterly lags of 4 quarter averages of the variables. This timing outperformed using the $\mathrm{t}-1$ annual readings of the averages of these variables over q3 and q4 readings in year t-2 and q1 and q2 readings in year $\mathrm{t}-1$.
} 
Our error-correction models of small loan share for each bank category are specified as:

$$
\begin{aligned}
& S B S H_{t}^{e}=\alpha_{0}+\alpha_{1} * D F A_{t}+\varepsilon_{t} \\
& \triangle S B S H_{t}=\beta_{0}+\beta_{1} E C_{t-1}+\sum \beta_{2 \mathrm{i}} \Delta S B S H_{t-i}+\sum \beta_{3 \mathrm{i}} \Delta D F A S B_{t-i}+\beta_{4} X_{t-1}+\mu_{t}
\end{aligned}
$$

where $S B S H^{e}{ }_{t}$ is the equilibrium level of small loan share, $\varepsilon_{t}$ and $\mu_{t}$ are i.i.d. residuals, the error correction term $E C_{t-1}=S B S H_{t-1}-S B S H^{e}{ }_{t}$, and the vector $X_{t-1}$ of short-run variables includes the t1 lags of LiborSP and OutputGap. The estimation of long-run and any short-run relationships is joint following Johansen (1995), and depends on the exogenous short-run factors included (the vector $X$ ). In general, we estimated a set of models that include a minimal number of short-run variables and also models with additional highly relevant short-run factors as a robustness check and to address concerns about the choice of such variables. Lag length was chosen to minimize the lags needed to find a unique significant cointegrating variable and, if possible, yield clean residuals. Estimation allows for possible time trends in long-run variables without an independent time effect in the vector aside from measured factors.

Table 1 reports estimates of six models, with two models estimated for each of the three asset size classes of banks, with odd-numbered models omitting the output gap and Libor spread, and the even-numbered models including them. For each model with these cyclical controls, a unique and significant cointegrating vector is identified, with DFASB having a significant, negative long-run impact of lowering the small loan share by 9 percentage points. The magnitude of this effect is about twice as large for small banks, consistent with the view that in addition to raising the fixed costs of making small loans at all banks, DFA's effect is more pronounced at small banks that do not benefit from economies of scale as much as large banks. Of the models lacking such controls, a significant and unique vector was only identified for the small loan share 
at large banks. To some extent, this may reflect a slightly longer sample period for large banks and that by using a relative size definition to create this subset of banks, it may not be distorted by migration arising from using a fixed nominal cutoff to define it—something affecting the other two bank classes. Consistent with these advantages, the standard error is lowest and the corrected R-square is highest for the large bank model among models with cyclical controls and among those without them. The model for large banks that includes cyclical controls yields model predictions that nicely track the evolution of the small loan share of C\&I loans, as shown earlier in Figure 4.

In every model of changes in the small loan share, the error-correction term is at least marginally significant with a negative sign indicating that short-run movements tend to reduce disequilibria. In the models with both cyclical controls, the error-correction term is significant at the 99 percent confidence level, with annual speeds of 43 to 53 percent at all and large banks, respectively, and a slower but still significant speed of 27 percent for small banks. In every case, the Libor spread has a negative and significant effect. While the output gap is always significant, it has a positive sign for the small bank subset and a negative one for all and large bank groupings. This difference plausibly reflects the balance of the earlier mentioned countervailing effects. When output gaps are high in strong business cycle upswings, small banks that typically have very few large clients, may likely ease credit standards for loans to small firms. At large banks, borrowing by large firms to build up desired inventory levels may lead larger firms to borrow more when the output gap is very positive and this effect may outweigh any increased borrowing by small firms, thereby pushing down the small loan share in periods of high positive output gaps at large banks (which dominate loan volumes for the banking industry).

We also tested the robustness of our key findings to controlling for other factors that might explain or account for the time series behavior of the small loan share. These include using two 
different ways of controlling for migration of loans from one nominal loan size category to another, as well as including controls for the aging of the U.S. population and possible hysteresis-like effects from the financial damage to households from the Great Recession and the financial and housing crisis of the late 2000s. As discussed in more detail in Appendix A, our key finding that the DFA has lowered the small loan share is robust to including controls for these effects.

\section{Evidence From Bank Credit Standards for C\&I (Business) Loans}

The previous section's results are from a reduced-form model, which may not provide fully convincing proof that the DFA affected the loan supply channel. In particular, if the DFA raised the fixed costs of making business loans, then the DFA would directly reduce the supply of smallsized loans relative to other loans at each bank. In addition, because the DFA's cost impact has induced a disproportionate consolidation of smaller banks, whose C\&I loan portfolios are more heavily weighted toward small-sized business loans, the DFA indirectly reduces loan supply more for small-sized loans than for larger-sized loans by directly decreasing the prevalence of small banks. Both the direct and indirect effects imply the testable hypothesis that the DFA would induce C\&I loan standards to be tightened more for C\&I loans to small-sized firms than to larger firms.

To assess this empirical implication - which also tests for a loan supply impact of the DFA — this section examines quarterly data from the Federal Reserve Board's Senior Loan Officer Opinion Survey (SLOOS) on Bank Lending Practices which, since 1990:q3, has asked banks about how their credit standards for C\&I loans to different size firm categories have changed relative to three months earlier. We define the relative change in credit standards on small versus large firms ( $\triangle$ CSGap) as the net percent change in banks tightening credit standards on C\&I loans to smallsize firms minus that on loans to medium- and large-size firms. This variable is stationary and we regress it on a set of stationary variables. 
Following Aron, et al. (2010) and Bordo, et al. (2016), potential variables for modeling $\triangle C S G a p$ are based on implications from the screening model of Stiglitz and Weiss (1981, part IV). That model implies that credit standards on a particular type of loan would be tightened if the real federal funds rate (the riskless real rate) rose, the economic outlook worsened (perhaps proxied by the percent change in the leading economic indicators), loan quality diminished (perhaps proxied by the change in loan delinquency rates), or if the burden of bank regulation rose (which effectively raises banks' cost of making loans). Aron, et al. (2010) and Bordo, et al. (2016) track these respective general types of variables with the change in the real federal funds rate $(\triangle R F F)$, the percent change in the index of leading economic indicators $\left(\triangle^{2} L E I\right)$, the year-over-year change in consumer installment or overall delinquency rates $\left(\triangle^{4} D E L\right)$ rose, and pre-1983 bank regulations (Aron, et al., 2012) or economic policy uncertainty (Bordo, et al., 2016), respectively. ${ }^{7}$ Aron, et al. also include the change in the 3-month LIBOR-Treasury interest rate spread ( $\triangle$ LiborSp) to control for changes in banks' marginal funding costs beyond those tracked by changes in the real federal funds rate, while Bordo, et al. (2016) use a dummy for the failure of Lehman in their shorter time series sample. We found that the change in the spread between Aaa-rated corporate and 10year Treasury bond yields ( $\triangle A a a T R$ ) outperformed $\triangle L i b o r S p$, perhaps reflecting distortions to the latter spread from Federal Reserve interventions in providing new lender-of-last-resort facilities during the crisis and false reporting of individual bank rates that were later used to calculate LIBOR. For a variable like $\triangle C S G a p$, which tracks the difference in changes in credit standards, such variables would only be significant if they affected the relative setting of credit standards on the small- versus large-firm categories. We regressed $\triangle C S G a p$ on the same definitions of $\triangle R F F$,

\footnotetext{
${ }^{7} \triangle R F F$ is the first difference of the nominal federal funds rate minus the year-over-year percent change in the personal consumption expenditures deflator. $\Delta^{2} L E I$ is the percent change in the Conference Board's index of leading economic indicators between, t-2 and t. $\triangle^{4} D E L$ is the year/year change in C\&I delinquency rates (Federal Reserve Board data).
} 
$\triangle^{2} L E I$, and $\triangle A a a T R$. For $\triangle^{4} D E L$ we instead tried the year-over-year change (and various shorter changes) in the Federal Reserve Board series on C\&I loan delinquency rates at all banks.

For regulatory variables, we included a dummy for the first period of Dodd-Frank (DFASB1), which equals 1 from the quarter (2009:q4) when the original version of the DFA was approved by the U.S. House of Representatives through 2014:q3, just after which the Federal Reserve announced that it would ease the regulatory burden of the DFA on smaller banks starting in early 2015. The timing of the DFA effects is faster in our model of credit standards than of loan shares because the former more quickly reflects banks' anticipation of future conditions affecting loan returns whereas loans outstanding tend to move with a lag after loan policy changes and reflect the stock of outstanding loans rather than terms on new loans.

As noted by Hunter (2015), the Federal Reserve's tailoring of the DFA to smaller depositories in 2015:q1 included 1) allowing small savings and loan associations to meet easier debt limitations that small banks enjoyed; 2) expanding easier debt limits for depositories with under \$500 million in assets to a higher threshold of under \$1 billion in assets; 3) eliminating a number of quarterly and complex financial reporting requirements for many institutions; and 4) eliminating many detailed capital items for small savings and loan associations. ${ }^{8}$ For the less stringent period of the DFA, we include a shift dummy to control for any remaining effect of the DFA on credit standards for loans to small versus large firms. This variable, DFASB2, equals 1 only since 2014:q4. If the Federal Reserve’s 2014 announcement provided regulatory relief that

8 For the third and fourth numbered actions, Hunter (2015) lists eliminating "quarterly and more complex consolidated financial reporting requirements (FR Y-9C) for approximately 470 of these institutions, and instead required parentonly financial statements (FR Y-9SP) semiannually;" and eliminating "all regulatory capital data items that were to be reported on the FR Y-9SP for approximately 240 savings and loan holding companies with less than \$500 million in total consolidated assets.” 
affected relative credit standards, the magnitude of the coefficient on DFASB1 should exceed that of the one on DFASB2.

We regressed $\triangle C S G a p$ on the full set of variables, and took the approach of progressively dropping the least significant of the insignificant variables. Only $\triangle^{2} L E I$ was dropped, leaving the following baseline and regulatory specifications:

$$
\begin{aligned}
& \triangle_{\text {CSGap }_{\mathrm{t}}}=\beta_{0}+\beta_{1} \Delta R F M_{\mathrm{t}-1}+\beta_{2} \Delta^{4} D E L_{\mathrm{t}-1}+\beta_{3} \Delta \text { AaaTR }_{\mathrm{t}-1}+\varepsilon_{\mathrm{t}} \\
& \Delta \operatorname{CSGap}_{\mathrm{t}}=\beta_{0}+\beta_{1} \Delta R F M_{\mathrm{t}-1}+\beta_{2} \Delta^{4} D E L_{\mathrm{t}-1}+\beta_{3} \Delta \operatorname{AaaTR}_{\mathrm{t}-1}+\beta_{3} D F A 1_{\mathrm{t}}+\varepsilon_{\mathrm{t}}
\end{aligned}
$$

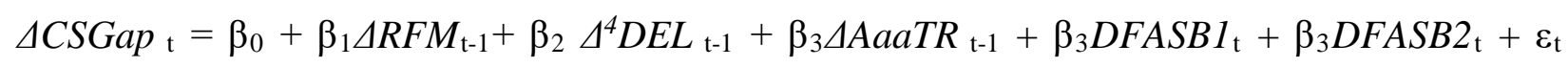

Table 2 reports results for estimating several models, all of which include an AR(1) correction for serial correlation in the residuals. The baseline Models 1 and 2 estimate equation (2) over the full (1990:q3-2017:q1) and pre-DFA (1990:q3-2010:q2) samples, respectively. Using the full sample, Model 3 estimates equation (3) that adds DFA1 to the baseline model, and Model 4 estimates equation (4) that adds DFASB1 and DFASB2 to the baseline model.

There are several common patterns across all of the models. First, $\triangle R F M$ generally has at least a marginally significant, positive coefficient whose magnitude implies that a one percentage point rise in the real federal funds rate induces two percent more banks to tighten credit standards on loans to small businesses than on loans to larger entities. ${ }^{9} \Delta$ AaaTR has a negative, significant

\footnotetext{
${ }^{9} \triangle R F M$ outperformed an alternative funds rate measure accounting for unconventional monetary policy. In other regressions which replaced $\triangle R F M$ with the first difference of Leo Krippner's shadow federal funds rate measure minus the same PCE inflation adjustment and found notably worse model fits with DFA and SOX terms remaining significant. This may reflect that bankers' incentives to make C\&I loans are more driven by short-term funding rates and are positively related to the slope of the yield curve but are less stimulated by quantitative easing which (lowers the shadow fed fund rate), by lowering long-term interest rates, tends to flatten the yield curve, diminishing the gains from banks borrowing short from depositors and lending at medium to long-term loan interest rates.
} 
sign implying that a widening of this risk premium induces relatively less tightening of credit standards on loans to smaller businesses. The negative signed effect is plausible because larger banks tend to rely more on borrowed funds and tend to make relatively fewer loans to small businesses. Ostensibly, as the cost of borrowed funds rises, it raises funding costs more at larger banks, which induces a tightening of credit standards more prevalent on loans to larger business than to smaller ones. Another pattern is that $\triangle^{4} D E L$ has a negative and significant sign, implying that a rise in the nation-wide C\&I delinquency rate induces relatively less tightening of credit standards on loans to smaller businesses. This could reflect that a value-weighted national delinquency rate is more reflective of loan quality for nationally exposed larger banks that make relatively fewer loans to small businesses and more to larger firms.

With respect to the effects of the DFA, the dummy for the most stringent period of the DFA on small banks, DFASB1, is statistically significant and positive in Models 3 and 4. The magnitude of the estimated coefficient implies that the DFA induced four percent more banks to tighten credit standards on loans to small firms than on loans to larger ones. This effect is economically significant insofar as it occurs, on average, for each quarter from 2009:q4 to 2014:q3, implying a large cumulative effect that is consistent with the results for the small-sized loan shares outstanding reported in Section III. The variable (DFASB2) controls for the possible effects of the DFA, starting with the Federal Reserve's late 2014 announcement of regulatory easing moves, and is insignificant and close to zero. This suggests that the regulatory relief measures had helped stop the DFA from further disproportionately affecting small business lending. However, the lack of a positive and significant coefficient suggests that the actions have not reversed the earlier relative tightening of credit standards on C\&I loans to small- versus large-sized businesses. Overall, the results indicate that the DFA did reduce the supply of loans more for small businesses than for 
larger firms, and that regulatory relief for smaller depositories has stabilized the relative level of credit availability for small versus larger businesses that occurred from 2010 to 2014. 


\section{Financial Regulation and Business Formation}

Thus far, evidence has been presented that the DFA has reduced both the share of C\&I loans that are small sized and the relative supply of bank loans to small versus larger firms. Comprehensive time series data on all sources of funding to nonpublic firms, however, are not available to assess to what extent bank lending effects from the DFA have been offset by increased use of nonbank sources of funding, such as private equity or loans from nonbanks. As an alternative way to analyze the net and real effects of the DFA on small business, we assess whether financial regulations, such as the DFA, have altered the pace at which new firms are formed.

As stressed by several studies, most notably Decker, et al. (2014, 2016a), there has been a notable decline in U.S. business creation that predates the Great Recession. More recent papers have studied some of the macroeconomic ramifications of the slowdown in business entry. For example, because productivity grows rapidly early in the life cycle of firms, slower business entry can lower the aggregate pace of productivity growth, contributing to the downshift in long-run growth since the early 2000s, as argued by Alon, et al. (2017). Likely compounding the impact of reduced entry rates on innovation and economic growth is the marked decrease in the share of new firms that have subsequently grown rapidly (Decker, et al. 2016b) and which had often been funded by venture capital in much of the 1980s and 1990s (Gornall and Strebulaev, 2015).

We use quarterly data spanning 1993:q1-2017:q3 from the Bureau of Labor Statistics (BLS) to track the birth rate (Birth) of new private establishments in the U.S. (BLS uses data on firm births and deaths to adjust payrolls at sampled firms to project nonfarm payroll employment.) Because smaller firms tend to be younger, there are parallels between modeling small business lending and business formation. And as shown earlier in Figure 1, the quarterly birth rate was unusually depressed from the onset of the Great Recession to late 2014. While annual data are available back to 1983 (and allow for some disaggregation by industry), the greater number of 
degrees of freedom using quarterly data are more suitable given the short time span covered and the time series aspects of the regulatory variables considered.

Because there are no published time series models of the birth rate, we experimented with various time series data to build simple empirical models of this stationary series. We found two consistently significant time series variables: the change in the civilian unemployment rate $(\Delta U)$ and the spread between yields on Aaa-rated corporate and 10-year Treasury bonds (AaaTr). The former helps control for the cyclical impact of economic slack on entrepreneurs' incentives to expand capacity and to undertake entrepreneurial risk, while the latter helps to more directly control for the cyclical influences of risk on entrepreneurs' incentives to start new firms. Both variables, via gauging cyclical influences on creditors’ or investors’ incentives to provide external finance, likely also track cyclical changes in entrepreneurs’ ability to obtain external funding.

To these we add three regulatory variables to assess whether regulations on bank and equity finance affected the pace of business formation. Two are DFASB1 and DFASB2, which track the impact of the two phases of the DFA on the overall availability of bank credit to entrepreneurs that may stem from the effects of regulations not only on C\&I lending, but also on access to consumer and real estate loans which small businesses might also use for funding. We supplement these terms with the regulatory regime shift variable, $S O X$, which equals 1 since the passage of the Sarbanes-Oxley Act) in 2002:q3, which we and Atkinson and Duca (2017) argue has increased the fixed costs of forming businesses with the eventual aim of publicly incorporating. This hypothesis is consistent with recent studies.

In examining detailed CPS data, Kozeniauskas (2017) finds that entrepreneurship rates among households have fallen across all age groups, and in a calibrated model of endogenous business formation, he demonstrates that higher fixed entry costs could plausibly for much of the 
slowdown in business entry rates. As discussed by Atkinson and Duca (2017), SOX raised the fixed and variable costs of firms to shift from being privately held to being publicly traded. This lowers the present value of young firms that would seek to become public, thereby reducing the incentives for venture capitalists to fund startups and young companies with the eventual goal of cashing out of their positions following an initial public offering.

Atkinson and Duca (2017) find that SOX primarily reduced venture capital investment by diminishing the positive impact of real Nasdaq stock prices on venture capital investment. Their statistically significant findings also implied economically significant effects, with SOX reducing the level of venture capital by roughly 40 percent below what pre-SOX relationships would imply. Arguably, SOX could have been among the factors that have raised the overall fixed costs of starting new businesses, which Kozeniauskas (2017) argues is a key driver of the slower pace of business formation in recent decades.

The present study tests for SOX effects on firm entry rates in two ways. The first simply adds the dummy SOX to the two cyclical and DFA regime variables in equation (4):

$$
\operatorname{Birth}_{\mathrm{t}}=\beta_{0}+\beta_{1} \Delta U_{\mathrm{t}-1}+\beta_{2} \operatorname{BaaTr}_{\mathrm{t}-1}+\beta_{3} D F A S B 1_{\mathrm{t}}+\beta_{4} D F A S B 2_{\mathrm{t}}+\beta_{5} S O X_{\mathrm{t}}+\varepsilon_{\mathrm{t}}
$$

The second approach adopts a Tobin's Q approach to modeling the business formation rate by adding a proxy for Tobin's Q to eq. (5) and instead of seeing whether SOX affects the intercept, adds the SOX dummy interacted with Tobin's Q as in the following specification:

$$
\begin{aligned}
& \operatorname{Birth}_{\mathrm{t}}=\beta_{0}+\beta_{1} \Delta U_{\mathrm{t}-1}+\beta_{2} \operatorname{BaaTr}_{\mathrm{t}-1}+\beta_{3} \text { DFASB }_{\mathrm{t}}+\beta_{4} \text { DFASB2 }_{\mathrm{t}}+\beta_{5} \text { Tobins }_{\mathrm{t}-2} \\
& +\beta_{6} \text { Tobins } Q_{\mathrm{t}-2} S O X_{\mathrm{t}}+\varepsilon_{\mathrm{t}}
\end{aligned}
$$

Specifically, we measure Tobin's Q with the ratio (TobinsQ) of the stock market capitalization of nonfinancial corporations to the replacement cost (historical basis) using Federal Reserve data from the Financial Accounts of the U.S. The t-2 lag fit the data best and reflect a reasonable lag 
of the effect of stock prices on entry. In principle, as TobinsQ rises, there is a greater incentive to expand existing companies and to start new ones, implying that the coefficient $\beta_{5}$ on Tobins $Q$ should be positive. The inclusion of SOX interacted with TobinsQ tests whether the incentive effects of Tobin's Q on business formation are smaller in magnitude during the subsample when SOX is in effect. By raising hurdle rates of return, the higher fixed costs entailed by SOX have plausibly reduced the positive impact on business formation of our Tobin's Q proxy, which does not account for shifts in the fixed costs of opening new firms. Hence, the coefficient $\beta_{6}$ on the interaction term, Tobins $Q_{\mathrm{t}-2} S O X_{\mathrm{t}}$, should be negative.

Table 3 presents results from estimating eight versions of eq. (5) using establishment birth rate data available since 1993:q2. All but one of these models include a correction for first order autocorrelation in their residuals. The first four specifications do not include a role for Tobin's Q, while Models 5-8 include Tobin's Q effects. Model 1 estimates eq. (5) over the full sample (1993:q2-2017:q1) omitting the three regulatory variables. Model 2 estimates Model 1 over the pre-DFA sample 1993:q2-2010:q2. Model 3 adds a time trend to Model 1 and is estimated over the full sample. Model 4 is estimated over the full sample and includes all three regulatory dummy variables as separate regressors in equation (5), which allows for SOX to have a simple intercept effect on business formation. Models 5 and 6 include the non-interactive proxy for Tobin's Q, with Model 6 also including an additional term interacting TobinsQ with $S O X \cdot{ }^{10}$ In this way, Model 6 mimics Atkinson and Duca (2017), who test whether the positive effect of real Nasdaq stock prices on venture capital investment has been weaker since the passage of SOX and find a statistically and economically significant negative coefficient on real Nasdaq stock prices interacted with a SOX

\footnotetext{
${ }^{10}$ In another regression which includes TobinsQ, SOX, and SOX*TobinsQ, the two SOX variables each have the negative expected sign, but are individually insignificant, likely reflecting multi-collinearity. Because hypothesized SOX effects are motivated by stock price incentives to form businesses, Table 3 presents the model dropping the noninteractive SOX variable for reasons related to internal consistency.
} 
regime dummy. Model 7 drops this interactive term, but includes both DFA regime variables. Comparing Models 6 and 7 helps assess whether accounting for SOX effects might alter estimates of the impact of the DFA.

Several patterns emerge across Table 3. First, the models omitting the DFA and SOX variables have serial correlation in errors and have poorer fits than the model including those variables. As expected, the DFA dummy for the most stringent periods is highly significant and negative in Models 4 and 6. In a slight contrast, the DFA dummy for the post 2015:q1 period is only marginally significant with a negative sign in Models 4 and 6, suggesting that if the DFA is still slowing business formation, the effect is less than that prior to the easing of some DFA regulations on smaller banks. Nevertheless, standard errors imply that the difference between the coefficients on DFASB1 and DFASB2 is not significant.

Comparing Models 3 and 4 suggests that the downturn in business formation is not simply a time trend, but reflects breaks in trends that coincide with major changes in financial regulation. Indeed a Quandt-Andrews test of stability finds a significant break in Model 3 in 2002:q3 (the maximum Wald F-statistic equals 58.39, significant at the 99.9 percent level), when SOX was passed. In other regressions, the time trend is insignificant when added to Model 4. Figure 8 plots the equilibrium values implied by the coefficients from these models, illustrating that the equilibrium implied by the regulation model (Model 4) more closely tracks the actual birth rate.

The coefficients from Models 4 and 6 suggest that efforts to modify the DFA have helped reduce — but not fully eliminate-its earlier negative effects on business entry, whereas the negative effects of SOX have persisted. The former pattern — which relates to the level of business formation-is consistent with the prior section's evidence that the regulatory relief initiated in 2015 helped stop a further relative tightening of credit standards on small-sized loans, but did not 


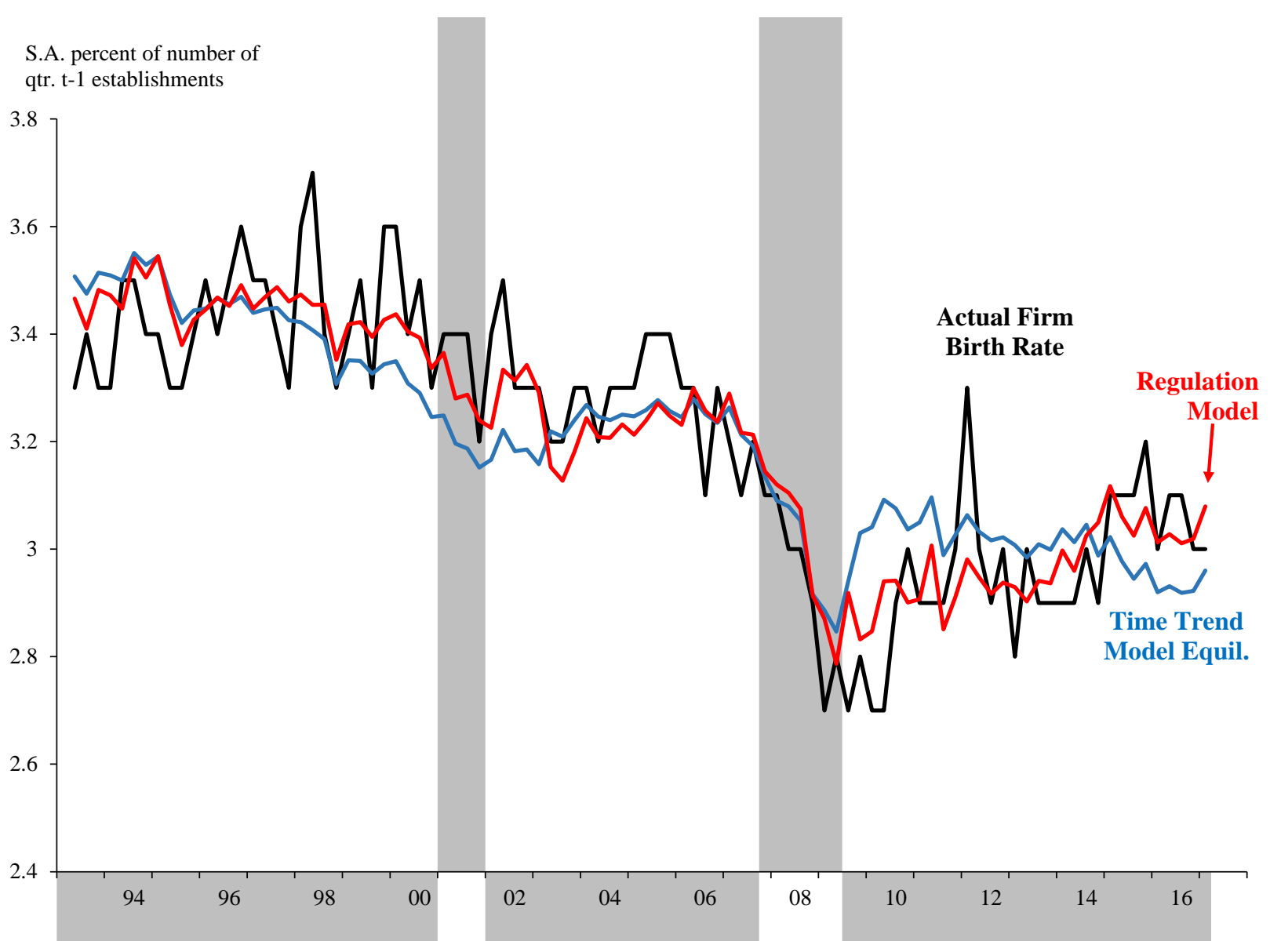

Figure 8: Financial Regulations Help Account For Business Formation, Simple Reg. Model. Shaded areas denote recessions. Sources: Bureau of Labor Statistics and authors' calculations.

unwind the prior relative tightening. By implication and consistent with the loan share analysis of Section 3, the level of lending to small firms appears to have been relatively reduced during the early implementation of the DFA, bottoming out when regulatory relief arose, the latter of which lessened the negative effects of the early implementation of DFA on business formation.

Models 4 and 6 also provide evidence that SOX has reduced the pace of business formation. In Model 4, this effect takes the form of a significant and negative coefficient on the noninteractive SOX dummy. In principle, however, SOX should affect business formation by reducing the incentive for new firms to enter when Tobin's Q is high. In Model 5, the non- 
interactive Tobin's Q variable has a positive, but statistically insignificant coefficient. This result could reflect that an omitted regime change has altered the effect of Tobin's Q over the full sample. Consistent with this interpretation, in Model 6 the non-interacted Tobin's Q variable has a positive and significant coefficient—which plausibly reflects an efficient response of business formation to market signals—while Tobin’s Q interacted with SOX has a negative and significant coefficient. Interestingly, the magnitudes of the coefficients and their standard errors imply that the effect of Tobin's $Q$ in the SOX era (the sum of $\beta_{5}$ and $\beta_{6}$ ) is not statistically different from zero. This implies stock prices have a weaker positive effect on business formation since SOX's passage. The magnitude of this effect is shown in Figure 9. The Tobin's Q model that accounts for DFA and SOX effects (Model 6) estimates a path that closely tracks business formation. The dashed line is a static forecast since SOX's passage based upon a model (Model 8) estimated over a preSOX sample (1993:q2 - 2003:q2) when the three regulatory dummies are irrelevant. The gaps between this path and the actual as well as between this path and the Model 6 in-sample prediction suggests that the business formation rate was an economically significant 10 percent below what pre-Sox behavior would have predicted. (Interestingly, the coefficient on the non-interactive Tobin's Q variable is not only highly significant in Model 8 (unlike Model 5), but is also similar in magnitude to that estimated in the full regulation model (Model 6). ${ }^{11}$

Also noteworthy when comparing Models 5 and 6, the addition of the interactive SOX and Tobin's Q variable improves model fit by a noticeable 0.06 in terms of the corrected $\mathrm{R}^{2}$, lowers the model standard error by $13 \%$, and eliminates serial correlation in the residuals present in the Tobin's Q model that omitted significant regulatory terms. Comparing Models 6 and 7 reveals that not controlling for significant SOX effects may understate the impact on business formation

\footnotetext{
${ }^{11}$ Although the corrected $\mathrm{R}^{2}$ is much lower in Model 7 than in Model 6, the model standard errors are similar.
} 


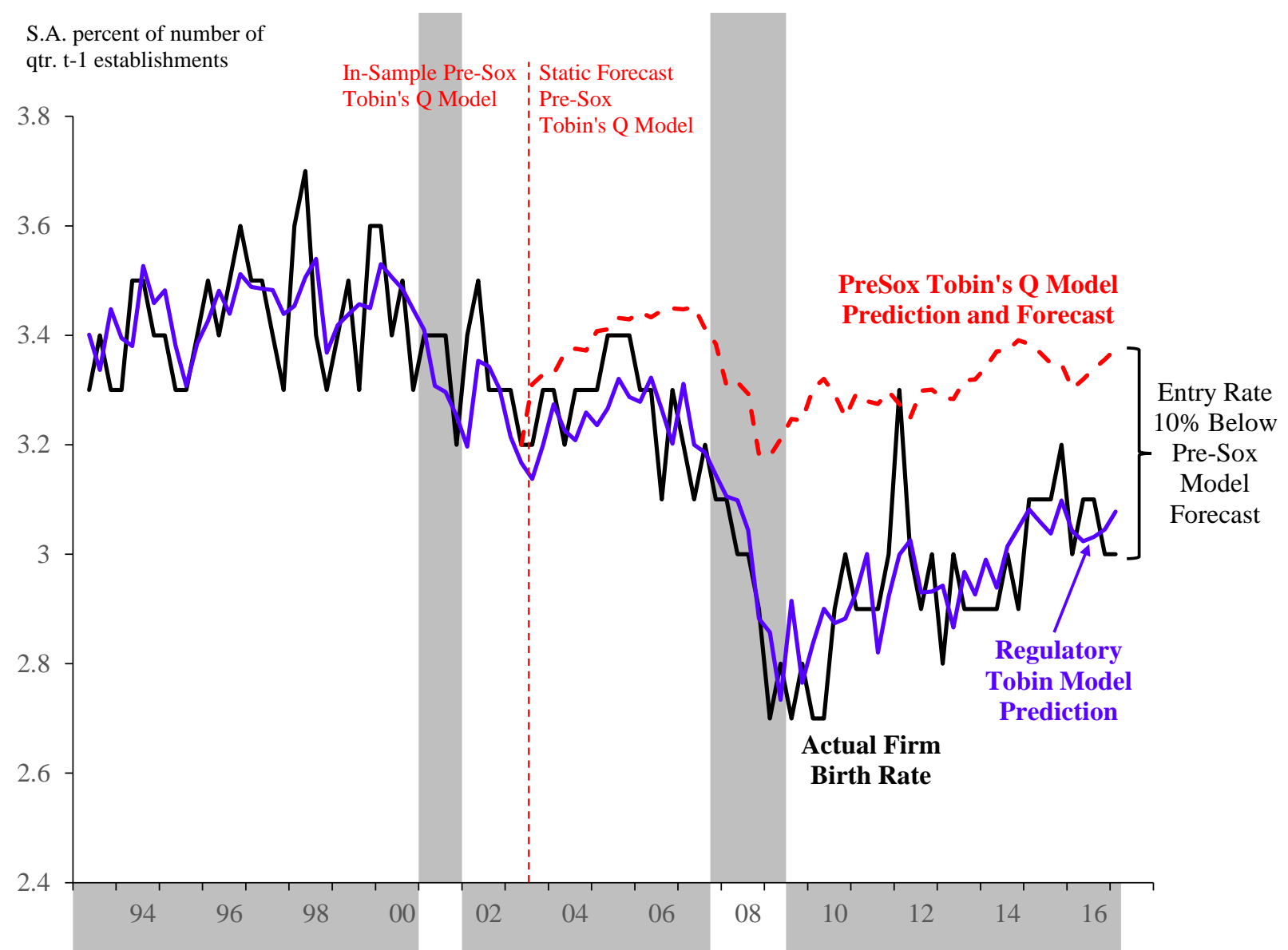

Figure 9: Business Formation Slower Than Pre-Sox Model Tobin’s Q-Based Forecast. Shaded areas denote recessions. Sources: Bureau of Labor Statistics and authors' calculations.

of 2015 actions to relieve the regulatory burden of DFA on smaller banks. In particular, the magnitude of the negative coefficient on DFASB2 is noticeably smaller (though not significantly so) in Model 6 than in Model 7, and DFASB2 switches from being highly significant in Model 7 to being only marginally significant in Model 6.

Finally, in regressions not shown, our results in model 6 were robust to including a control for household wealth (the wealth-to-disposable income variable in the Financial Accounts of the U.S.), which could help control for hysteresis effects from the damage to wealth from the Great Recession and the financial and housing crisis. This was insignificant, perhaps reflecting multicollinearity with the inclusion of wealth effects via the Tobin's q variables. In other runs not 
shown, we also included the growth rate of the working age (age 25 to 54) population to control for possible effects of slowing population growth among those at a life-cycle stage conducive to forming a business. This also proved insignificant, possibly because the slowdown in working age population growth began in the early 1990s—nearly a decade before the slowdown in business formation that began around the time SOX was passed in the early 2000s. ${ }^{12}$

Coupled with persistent negative effects of SOX on business formation, the patterns of results and coefficients on the early and late stages of the DFA implementation suggest that there may be more scope to reviving business formation through further review of the increased regulation of equity markets under SOX than further modifying banking regulations under the DFA.

\section{Conclusion}

Owing to economies of scale, the increased fixed costs of complying with loan regulations have reduced the incentives for individual banks to make small-sized loans (Covas, 2017) and have induced greater consolidation of the banking industry (Dahl, et al., 2016, and Reichow, 2017), away from small banks that disproportionately have lent to small businesses. Consistent with concerns that the DFA has induced the banking industry to reduce lending to small businesses, we find strong evidence of a break in the downward trend in the small business share of C\&I loans that coincides with the passage of the DFA. The inclusion of controls for the business cycle along with the asynchronous timing of the economic recovery and the plunging small business loan share imply that most of the recent downtrend stems more from the DFA-induced regulatory response

\footnotetext{
12 Although the Affordable Care Act (ACA) also passed in 2010, it unlikely accounts for the estimated DFA effects for three reasons. First, many small firms were exempt from the ACA's requirements for employers to provide health insurance. Second, the implementation of the ACA occurred well after the large downshift in small loan share in 2011. Third, ACA effects cannot really account for the differential effects of the DFA on changes in bank credit standards and on business formation before and after regulatory relief from the DFA was announced in 2014.
} 
to the Great Recession rather than the non-regulatory impact of that downturn. Since 2010, the small business share of C\&I loans has fallen by 9 percentage points, and our results indicate that the vast bulk of this decline is linked to the passage of the DFA.

Other results indicate that banks credit standards for making C\&I loans became relatively tighter for small businesses compared with medium- and large-sized firms when DFA requirements were most onerous on smaller banking organizations. This set of findings implies that the DFA induced loan supply shifts away from small business lending. This further indicates that our findings on outstanding loans are not simply reflective of loan demand shifts that coincided with the DFA. Furthermore, loan supply survey data suggest that regulatory relief for smaller banking organizations in 2014 may have helped stop further intensification of the negative, unintended impact of the DFA on small business lending. In this way, our findings are loosely supportive of efforts to refine the DFA to better tailor it to the costs and benefits of regulating community banks as discussed by Hunter (2015) and Yellen (2016).

Partly to assess whether the negative effects of the DFA on small business lending were offset by increased use of other funding sources, we also analyze whether another set of financial regulations - those from SOX — have affected the pace of business formation. Statistically and economically significant coefficients on regulatory timing variables imply that the impact of the DFA and SOX on small and newer business' access to funding from banks and public equity markets has not been fully offset by increased reliance on other sources of finance.

Our study also provides evidence that the early stages of the DFA had a large negative effect on business entry, in contrast to a smaller and only marginally significant negative effect in latter stages, when small banks were granted some exemptions from some provisions of the DFA. This is especially the case when we also account for the effects of SOX. In particular, Atkinson 
and Duca (2017) and the current study are analogous in finding that recent financial reformsSOX of 2003 in the case of the former and the DFA of 2010 in the case of each—can sometimes have the unintended consequence of reducing the availability of finance to small firms. More broadly, these findings suggest that these financial reform acts have significantly contributed to increasing the fixed costs of starting firms, thereby slowing the pace of business formation in the U.S. ${ }^{13}$

Furthermore, we find timing patterns indicating that the relative tightening of bank credit standards on small versus large firms abated and the rate of business formation may have partly revived following efforts to provide regulatory relief to smaller banks via modified rules implementing the DFA. In contrast, the SOX appears to persistently restrain business formation (and venture capital investment according to Atkinson and Duca, 2017). Taken together, these results indicate that it may be fruitful to carefully reassess and perhaps tailor the regulation of equity markets under SOX, whereas there may be less scope for further reviving business formation by additional modifications to the DFA.

While we show evidence of some downside aspects of the DFA, our study should not be misinterpreted as providing evidence against other aspects of the DFA for which there is consensus of positive net benefits (e.g., higher capital requirements and stress tests for large institutions). Data limitations restrict how much one can infer from analyzing—in isolation—any one of the three aspects of small business activity examined here. However, when viewed together, findings on small business loans, bank lending supply policies, and small business formation provide consistent evidence that increased regulation from the Dodd-Frank as well as the Sarbanes-Oxley Acts have had the unintended consequence of impairing small business activity in the U.S.

\footnotetext{
${ }^{13}$ This is consistent with the broader framework and evidence provided by Kozeniauskas (2017).
} 
Table 1: Annual Models of the Small-Sized Loan Share of C\&I Loans

Long-Run Equilibrium: $S B S H_{t}=\alpha_{0}+\alpha_{1}$ DFASB $_{\mathrm{t}}+\varepsilon_{\mathrm{t}}$

Variables

\begin{tabular}{|c|c|c|c|c|c|c|}
\hline \multirow[b]{2}{*}{ Model No. } & \multicolumn{2}{|c|}{ All $\geq \$ 300$ Million } & \multicolumn{2}{|c|}{ Large (top 12\%) } & \multicolumn{2}{|c|}{ Small $(300 \mathrm{M} \leq$ assets $\leq \$ 1 \mathrm{~B})$} \\
\hline & 1 & 2 & 3 & 4 & 5 & 6 \\
\hline Constant & 0.2463 & 0.2541 & 0.2376 & 0.2449 & 0.6732 & 0.6826 \\
\hline$D F A S B_{\mathrm{t}}$ & $\begin{array}{c}-0.0608^{* *} \\
(3.91)\end{array}$ & $\begin{array}{c}-0.0927^{* *} \\
(8.22)\end{array}$ & $\begin{array}{c}-0.0669^{* *} \\
(8.90)\end{array}$ & $\begin{array}{c}-0.0903^{* *} \\
(14.42)\end{array}$ & $\begin{array}{c}-0.1464^{* *} \\
(3.50)\end{array}$ & $\begin{array}{c}-0.1822^{* *} \\
(5.81)\end{array}$ \\
\hline unique coint. & No & Yes $^{* *}$ & Yes $^{*}$ & Yes $^{* *}$ & No & Yes $^{*}$ \\
\hline vec. \# lags & 2 & 1 & 3 & 1 & 2 & 2 \\
\hline trace no vec. & 11.52 & $23.23^{* *}$ & $16.92^{*}$ & $34.59^{* *}$ & 7.27 & $15.82^{*}$ \\
\hline trace only 1 & 1.35 & 0.00 & 0.13 & 00.03 & 0.79 & 1.12 \\
\hline
\end{tabular}

Short-Run: $\Delta S B S H_{t}=\beta_{0}+\beta_{1} E C_{t-1}+\sum \beta_{2 i} \Delta S B S H_{t-i}+\sum \beta_{3 i} \Delta D F A S B_{t-i}+\beta_{4} X_{t-1}+\mu_{t}$

\begin{tabular}{|c|c|c|c|c|c|c|c|}
\hline $\begin{array}{l}E C_{\mathrm{t}-1}, \\
\text { 'adjustment speed' }\end{array}$ & $\begin{array}{l}-0.557^{*} \\
(2.66)\end{array}$ & & $\begin{array}{l}-0.425^{* *} \\
(3.77)\end{array}$ & $\begin{array}{l}-1.102^{* *} \\
(3.98)\end{array}$ & $\begin{array}{c}-0.529^{* *} \\
(4.67)\end{array}$ & $\begin{array}{r}-0.241^{+} \\
(1.81)\end{array}$ & $\begin{array}{l}-0.265^{* *} \\
(2.87)\end{array}$ \\
\hline$\Delta S B S H_{\mathrm{t}-1}$ & $\begin{array}{l}0.458^{+} \\
(1.92)\end{array}$ & & $\begin{array}{r}0.050 \\
(0.38)\end{array}$ & $\begin{array}{l}-0.657^{* *} \\
(2.94)\end{array}$ & $\begin{array}{r}0.043 \\
(0.35)\end{array}$ & $\begin{array}{r}0.152 \\
(0.69)\end{array}$ & $\begin{array}{r}-0.140 \\
(0.78)\end{array}$ \\
\hline$\triangle D F A S B_{\mathrm{t}-1}$ & $\begin{array}{r}-0.459 \\
(1.56)\end{array}$ & & $\begin{array}{l}-0.040^{+} \\
(1.86)\end{array}$ & $\begin{array}{l}0.011 \\
(0.31)\end{array}$ & $\begin{array}{r}-0.302 \\
(1.58)\end{array}$ & $\begin{array}{r}-0.056 \\
(1.67)\end{array}$ & $\begin{array}{l}-0.033 \\
(1.13)\end{array}$ \\
\hline$\Delta$ LiborSP ${ }_{\mathrm{t}-1}$ & & & $\begin{array}{l}-0.022^{*} \\
(2.38)\end{array}$ & & $\begin{array}{l}-0.027^{* *} \\
(3.02)\end{array}$ & & $\begin{array}{l}-0.055^{* *} \\
(3.74)\end{array}$ \\
\hline OutputGap $_{t-1}$ & & & $\begin{array}{l}-0.0037^{+} \\
(1.93)\end{array}$ & & $\begin{array}{c}-0.0033^{*} \\
(2.13)\end{array}$ & & $\begin{array}{c}0.0059^{*} \\
(2.24)\end{array}$ \\
\hline Constant & $\begin{array}{l}-0.001 \\
(0.23) \\
\end{array}$ & & $\begin{array}{l}0.003 \\
(0.45)\end{array}$ & $\begin{array}{r}-0.001 \\
(0.33) \\
\end{array}$ & $\begin{array}{l}0.021 \\
(0.44) \\
\end{array}$ & $\begin{array}{l}0.025 \\
(0.68)\end{array}$ & $\begin{array}{l}0.028^{* *} \\
(3.04)\end{array}$ \\
\hline Adj. $\mathrm{R}^{2}$ & 0.376 & & 0.651 & 0.538 & 0.706 & 0.267 & 0.572 \\
\hline S.E.x100 & 1.482 & & 1.085 & 1.218 & 0.939 & 1.950 & 1.490 \\
\hline VEC Auto (1) & & 1.76 & & 4.17 & 2.53 & 5.60 & 2.56 \\
\hline VEC Auto (2) & 3.74 & & 5.03 & 4.53 & 7.89 & 2.09 & 7.09 \\
\hline
\end{tabular}

Estimated using data spanning 1993-2016 or 1993-2017. Notes: (i) Absolute t-statistics in parentheses. ${ }^{* *}\left(^{*}\right)$ denotes significant at the 99\% (95\%) confidence level. Regressions use data since 1993. (ii) Long-run: Maximum likelihood estimates of the long-run equilibrium relationship using a two-equation system with at most one cointegrating vector. (iii) Short-run: OLS estimates of the speed of adjustment and short-run dynamics using the estimated equilibrium correction terms in (ii), $E C_{\mathrm{t}-1}=S B S H_{\mathrm{t}-1}-\alpha_{0}-\alpha_{1} D F A_{\mathrm{t}-1}$. (iv) First difference terms of elements in the long-run cointegrating vector after $\mathrm{t}-1$ and some short-run controls omitted to conserve space. (v) Lag lengths chosen to obtain unique significant vectors with sensible coefficients and clean residuals. 
Table 2: Quarterly Models of the Relative Change in Bank Credit Standards on C\&I Loans to Small versus Medium- and Large Size Firms (CSGap)

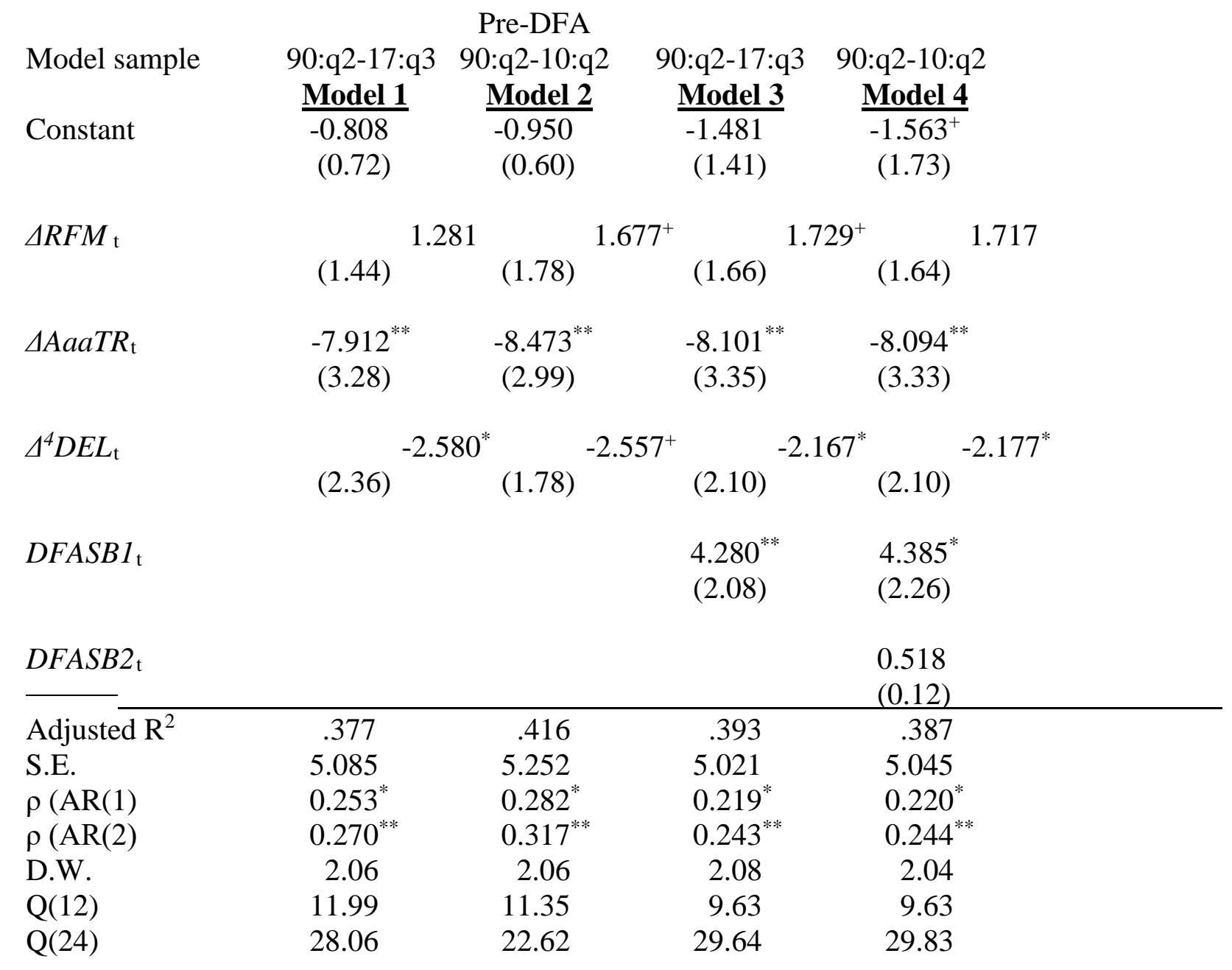

Notes: ${ }^{+*}$ and ${ }^{* *}$ denote $90 \%, 95 \%$, and 99\% significance levels, respectively. Absolute t-statistics are in parentheses. 
Table 3: Quarterly Models of the Birth Rate of Firms (Birth)

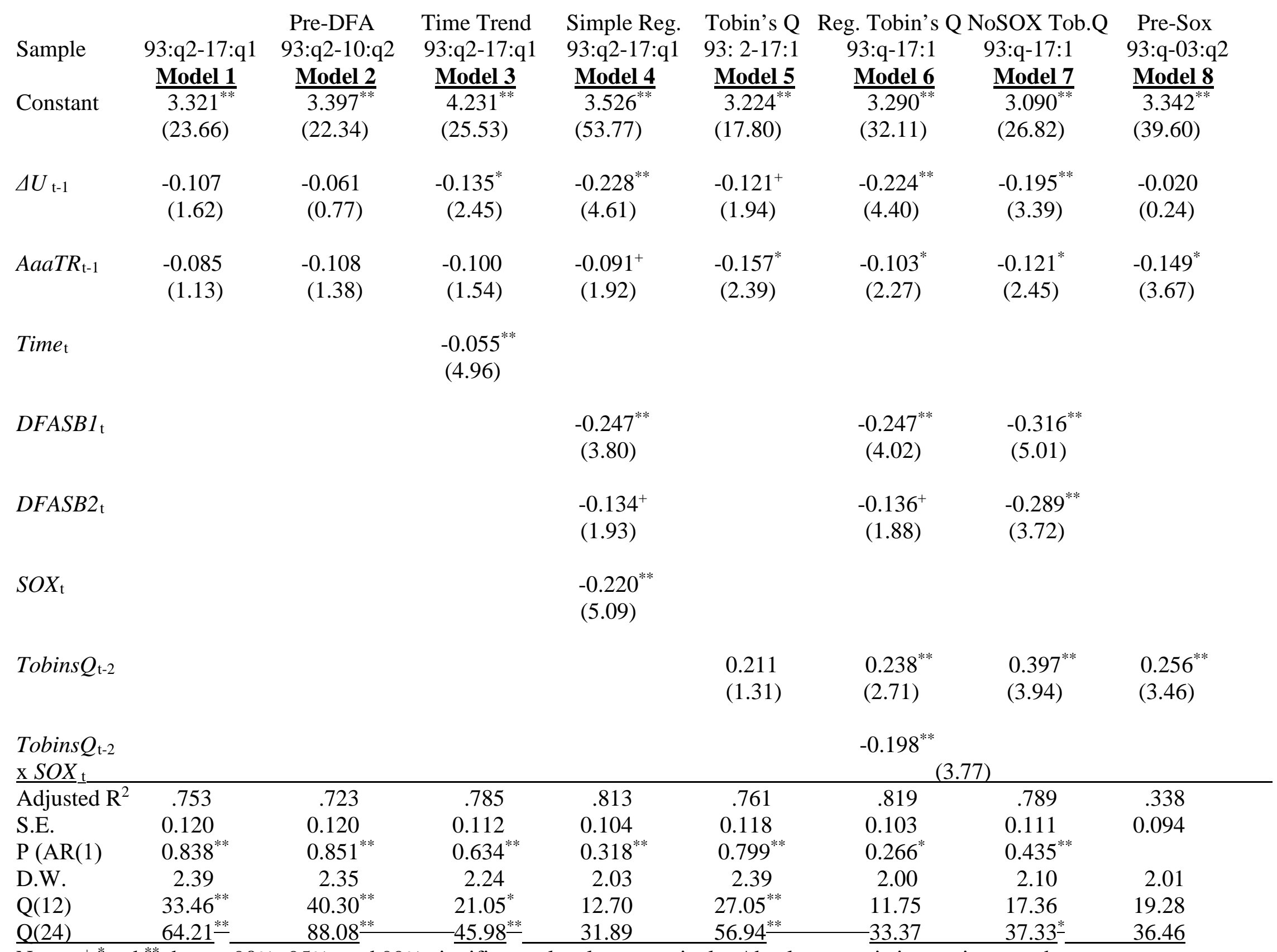

${\text { Notes: }{ }^{+*} \text {, and }}^{* *}$ denote $90 \%$, 95\%, and 99\% significance levels, respectively. Absolute t-statistics are in parentheses. 


\section{References}

Alon, Titan, Berger, David, Dent, Robert, and Pugsley, Benjamin (2017), “Older and Slower: The Startup Deficits Lasting Effects on Aggregate Productivity Growth,” National Bureau of Economic Research Working Paper No. 23875.

Aron, Janine, John V. Duca, John Muellbauer, Keiko Murata, and Anthony Murphy (2012),

“Credit, Housing Collateral, and Consumption: Evidence from Japan, the UK, and the U.S.,” Review of Income and Wealth 58(3), 397-423.

Atkinson, Tyler and John V. Duca (2017), “Equity Regulation and U.S. Venture Capital Investment,” Federal Reserve Bank of Dallas Working Paper 1707.

Bordo, Michael D., John V. Duca. and Christoffer Koch (2016), "Economic Policy Uncertainty and the Credit Channel: Aggregate and Bank Level U.S. Evidence over Several Decades.” Journal of Financial Stability 26, 90-106.

Covas, Francisco, 2017, “Capital Requirements in Supervisory Stress Tests and Their Adverse Impact on Small Business Lending,” TCH Working paper, August 2017.

Dahl, Drew, Andrew Meyer and Michelle Neely (2016), “Bank Size, Compliance Costs and Compliance Performance in Community Banking,” Federal Reserve Bank of St. Louis manuscript, www.communitybanking.org/ documents/2016-ConferencePapers/Session2_ Paper2_Neely.pdf ..

Decker, Ryan A., Haltiwanger, John, Jarmin, R.S., Miranda, Javier (2016a), “Declining Business Dynamism: What We Know and the Way Forward,” American Economic Review 106(5), 203-07. 
Decker, Ryan A., Haltiwanger, John, Jarmin, R.S., Miranda, Javier (2016b), “Where Has All the Skewness Gone? The Decline in High-Growth (Young) Firms in the U.S.,” European Economic Review 86, 4-23.

Decker, Ryan A., Haltiwanger, John, Jarmin, R.S., Miranda, Javier (2014), “The Role of Entrepreneurship in U.S. Job Creation and Economic Dynamism,” Journal of Economic Perspectives 28(3), 3-24.

Gornall, W., Strebulaev, I.A., (2015), “Economic Impact of Venture Capital: Evidence from Public Companies,” Stanford Business School Working Paper No. 3362, November.

Hunter, Maryann (2015), “Community Bank Regulations,” Testimony to the U.S. House of Representatives, Washington, DC, April 23, 2015. https://www.federalreserve.gov/newsevents/testimony/hunter20150423a.htm

Kozeniauskas, Nicholas (2017), “What’s Driving the Decline in Entrepreneurship,” manuscript, New York University, November 16, 2017.

Lux, Marshall and Robert Green (2015), “The State and Fate of Community Banking,” M-RCBG Associate Working Paper Series No. 37, Harvard Kennedy School, February. <https://www.hks.harvard.edu/content/download/74695/1687293/version/1/file/Final_Sta te_and_Fate_Lux_Greene.pdf>

Reichow, Kelsey (2017), “Small-Business Lending Languishes as Community Banking Weakens,” Federal Reserve Bank of Dallas Economic Letter 12(3), 1-4.

Stiglitz, Joseph E. and Andrew Weiss (1981), “Credit Rationing in Markets with Imperfect Information,” American Economic Review 71, 393-410. 
Yellen, Janet L. (2016), "Statement before the Committee on Financial Services, U.S. House of Representatives,” September 28,

$<$ https://www.federalreserve.gov/newsevents/testimony/yellen20160928a.pdf> 


\section{Appendix A: Robustness Checks For Modeling the Small Loan Share}

There are four sets of checks done to assess four potential concerns about the small loan share models in Table 1 and Section II. The first is that an uptrend in the general price level could cause substantial migration of loans from being under one million in nominal size to being over one million in nominal size. Unfortunately, detailed data on the distribution of individual loans is not available. Nevertheless, to address this concern, the level of the GDP implicit price deflator $(P G D P)$ is added to the cointegrating vector for each of the even-numbered models in Table 2 that contain the cyclical controls which cover the three different size categories of banks. These are numbered Models 2A, 4A, and 6A in Appendix Table A1. The nominal migration concern would imply a negative coefficient on the equilibrium effect of $P G D P$ on $S B S H$. However, in each of the models, the coefficient on PGDP has the opposite positive sign, while that on DFASB remains significant with the hypothesized negative sign.

The second concern with the models in Table 1 is that an uptrend in the level of per capital nominal GDP could cause substantial migration of loans from being under one million in nominal size to being over one million in nominal size. To address this issue, the level of per capita nominal GDP (NGDPC) is added to the same small loan share models, except that the lagged output gap was omitted to avoid collinearity issues. These are numbered Models 2A, 4A, and 6A in Appendix Table A1. The nominal migration concern would imply a negative coefficient on the equilibrium effect of PGDP on SBSH. However, in each of the models, the coefficient on NGDPC has the opposite positive sign, while that on DFASB remains significant with the hypothesized negative sign. Unique cointegrating vectors were not found for the Table A1 models for the classes of banks with at least $\$ 300$ million in nominal assets or with under $\$ 1$ billion. However, for the top 12 percent size category of banks - whose definition limits nominal migration affecting which 
banks report the data needed to construct $S B S H$-a unique cointegrating vector is identified for models $4 \mathrm{~A}$ and $4 \mathrm{~B}$. Furthermore, these models have the same long-run qualitative results for the impact of DFASB, and with a significant, negative estimated coefficient on the lagged errorcorrection term as the models in Table 1.

A third concern with the Table 1 results is that they may arise not because of the DFA, but because of a demographic slowdown in the adult population that may start businesses. To address this issue, the growth rate of the prime working age population, defined as being between ages 25 and 54 (Age2554) is added to the cointegrating vector of the Table 1 models that include the two cyclical control variables. These are numbered Models 2C, 4C, and 6C in Appendix Table A2. The demographic slowdown concern would imply a positive coefficient on the equilibrium effect of Age2554 on SBSH. However, in the models for the classes of banks with at least $\$ 300$ million in nominal assets or with under $\$ 1$ billion, the coefficient on NGDPC has the opposite negative sign, while that on DFASB remains significant with the hypothesized negative sign. For the more consistently tracked largest 12 percent of banks, NGDPC is insignificant, while DFASB continues to have a negative and significant long-run impact and in the short-run models the lagged errorcorrection term is negative and significant as in the Table 1 models. The poor performance of the demographic variable likely reflects that the slowdown in the growth rate of the working age population began in the 1990s, well before the downshift of the small business loan share that occurred following the passage of DFA in 2010 and also before the slowdown in business formation that began in the early 2000s, shortly after the passage of SOX.

A fourth concern with the Table 1 results is that they may arise not because of the DFA, but because of hysteresis effects from the Great Recession. These sorts of effects would reflect long-standing damage to households' ability to start businesses beyond the cyclical variables 
already in the models. To address this issue and use available data, the quarter end-of-year ratio of household wealth to disposable income (WIRatio) from the Financial Accounts of the U.S. is a good candidate variable for two reasons. First, it tracks wealth, which plausibly tracks lasting financial damage to households from asset busts. Second, it is scaled by disposable income which helps abstract from cyclical effects already controlled for in the Table 1 models. WIRatio is added to the cointegrating vector of the Table 1 models that include the two cyclical control variables. These are numbered Models 2D, 4D, and 6D in Appendix Table A2. The hysteresis-wealth effect concern would imply a positive coefficient on the equilibrium effect of WIRatio on SBSH. In all three models, significant and unique cointegrating vectors were identified with the expected and significant positive long-run effect of WIRatio on SBSH, as well as a continued negative and significant effect of DFASB. In the two larger bank asset categories, the short-run models perform well, with reasonably high fits and significant and negative coefficients on the error-correction terms. This was not the case for the small loan share at small banks, for which the original model that omitted WIRatio, but included DFASB performed much better. Nevertheless, the inclusion of the wealth ratio did not overturn the principal finding that the small loan share was negatively affected by DFA over the long-run. This result was also robust to the inclusion of the price level, nominal GDP, and a variable controlling for the aging of the U.S. working-age population. 


\section{Appendix Table A1: Annual Models of the Small-Sized Loan Share of C\&I Loans \\ Long-Run Equilibrium: $S B S H_{t}=\alpha_{0}+\alpha_{1}$ DFASB $_{\mathrm{t}}+\alpha_{2}$ PGDP $/$ NGDPC $_{\mathrm{t}}+\varepsilon \mathrm{t}$}

Bank Asset Size Classes

All $\geq \$ 300$ Million $\quad$ Large (top $12 \%) \quad$ Small $(300 \mathrm{M} \leq$ assets $\leq \$ 1 B)$

\begin{tabular}{|c|c|c|c|c|c|c|}
\hline Model No. & $2 \mathrm{~A}$ & $2 B$ & $4 \mathrm{~A}$ & $4 \mathrm{~B}$ & $6 \mathrm{~A}$ & $6 \mathrm{~B}$ \\
\hline Constant & 0.1378 & 0.1885 & 0.2198 & 0.2173 & 0.6732 & 0.3822 \\
\hline$D F A S B_{\mathrm{t}}$ & $\begin{array}{l}-0.1262^{* *} \\
(13.87)\end{array}$ & $\begin{array}{c}-0.1485^{* *} \\
(11.73)\end{array}$ & $\begin{array}{l}-0.1010^{* *} \\
(12.00)\end{array}$ & $\begin{array}{l}-0.1178^{* *} \\
(12.25)\end{array}$ & $\begin{array}{l}-0.3571^{* *} \\
(11.46)\end{array}$ & $\begin{array}{l}-0.2762^{* *} \\
(27.31)\end{array}$ \\
\hline $\begin{array}{l}\text { PGDP (A models) } \\
\text { NGDPC (B models) }\end{array}$ & $\begin{array}{l}0.0086^{* *} \\
(4.38)\end{array}$ & $\begin{array}{l}0.00002^{* *} \\
(4.18)\end{array}$ & $\begin{array}{c}0.0003 \\
(1.18)\end{array}$ & $\begin{array}{l}0.000008^{*} \\
\quad(2.24)\end{array}$ & $\begin{array}{l}0.0084^{* *} \\
(6.60)\end{array}$ & $\begin{array}{c}0.000008^{*} \\
(10.41)\end{array}$ \\
\hline unique coint. & No & Yes $^{* *}$ & Yes $^{* *}$ & Yes $^{* *}$ & No & No \\
\hline vec. \# lags & 1 & 1 & 1 & 1 & 2 & 2 \\
\hline trace no vec. & $66.26^{* *}$ & $42.34^{* *}$ & $61.51^{* *}$ & $37.58^{* *}$ & $46.67^{* *}$ & $77.99^{* *}$ \\
\hline trace at least 1 & $18.63^{* *}$ & 11.60 & 14.98 & 6.13 & 15.10 & $38.85^{* *}$ \\
\hline trace at least 1 & 3.34 & 1.72 & 0.64 & 1.60 & $3.99^{*}$ & 3.63 \\
\hline
\end{tabular}

$1^{+} \mu_{t}$

Short-Run: $\triangle S B S H_{t}=\beta_{0}+\beta_{1} E C_{t-1}+\sum \beta_{2 i} \Delta S B S H_{t-i}+\sum \beta_{3 i} \Delta D F A S B_{t-i}+\sum \beta_{4 i} \Delta P G D P / N G D P C_{t-i}+\beta_{5} X_{t-}$

\begin{tabular}{|c|c|c|c|c|c|c|c|}
\hline $\begin{array}{l}E C_{\mathrm{t}-1,} \\
\text { 'adjustment speed' }\end{array}$ & $\begin{array}{l}-0.717^{* *} \\
(4.35)\end{array}$ & $\begin{array}{l}-0.427^{* *} \\
(3.29)\end{array}$ & $\begin{array}{l}-0.810^{* *} \\
(5.20)\end{array}$ & $\begin{array}{l}-0.532^{* *} \\
(3.87)\end{array}$ & $\begin{array}{r}0.077 \\
(0.75)\end{array}$ & $\begin{array}{r}-0.022 \\
(0.05)\end{array}$ & \\
\hline$\Delta S B S H_{\mathrm{t}-1}$ & $\begin{array}{l}0.204 \\
(1.23)\end{array}$ & $\begin{array}{c}-0.338^{+} \\
(1.94)\end{array}$ & $\begin{array}{l}-0.178 \\
(1.28)\end{array}$ & $\begin{array}{l}-0.306^{*} \\
(2.13)\end{array}$ & $\begin{array}{l}-0.037 \\
(0.04)\end{array}$ & $\begin{array}{l}0.347 \\
(0.62)\end{array}$ & \\
\hline $\begin{array}{l}\triangle P G D P \text { (A models) } \\
\triangle N G D P C \text { (B models) }\end{array}$ & $\begin{array}{c}0.0004 \\
(0.08)\end{array}$ & $\begin{array}{l}-0.00001^{* *} \\
(3.37)\end{array}$ & $\begin{array}{l}0.0005 \\
(0.11)\end{array}$ & $\begin{array}{l}-0.00001^{* *} \\
(3.65)\end{array}$ & $\begin{array}{r}-0.014 \\
(1.44)\end{array}$ & $\begin{array}{r}-0.00004 \\
(0.36)\end{array}$ & \\
\hline$\Delta D F A S B_{\mathrm{t}-1}$ & $\begin{array}{r}-0.022 \\
(0.91)\end{array}$ & $\begin{array}{r}-0.025 \\
(1.10)\end{array}$ & $\begin{array}{l}0.019 \\
(0.02)\end{array}$ & $\begin{array}{r}-0.020 \\
(1.01)\end{array}$ & $\begin{array}{r}-0.060 \\
(1.47)\end{array}$ & $\begin{array}{r}-0.169 \\
(1.53)\end{array}$ & \\
\hline$\Delta$ LiborSP $_{\mathrm{t}-1}$ & $\begin{array}{l}-0.039^{* *} \\
(2.95)\end{array}$ & $\begin{array}{l}-0.046^{* *} \\
(3.35)\end{array}$ & $\begin{array}{l}-0.035^{* *} \\
(3.34)\end{array}$ & $\begin{array}{c}-0.043^{* *} \\
(3.94)\end{array}$ & $\begin{array}{r}-0.004 \\
(0.18)\end{array}$ & $\begin{array}{r}0.014 \\
(0.51)\end{array}$ & \\
\hline OutputGap $_{t-1}$ & $\begin{array}{c}-0.0044^{*} \\
(2.55)\end{array}$ & & \multicolumn{2}{|c|}{$(3.20)^{-0.0047^{* *}}$} & \multicolumn{2}{|c|}{$(0.62)^{0.0024}$} & \\
\hline Constant & $\begin{array}{r}0.001 \\
(0.23)\end{array}$ & $\begin{array}{l}0.035^{* *} \\
(4.06)\end{array}$ & $\begin{array}{l}0.006 \\
(0.66)\end{array}$ & $\begin{array}{l}0.032^{* *} \\
(4.50)\end{array}$ & $\begin{array}{l}0.024 \\
(0.03)\end{array}$ & $\begin{array}{l}0.035 \\
(1.17)\end{array}$ & \\
\hline Adj. $\mathrm{R}^{2}$ & 0.631 & 0.644 & 0.695 & 0.697 & 0.093 & 0.572 & \\
\hline S.E.x100 & 1.115 & 1.097 & 0.956 & 0.954 & 2.126 & 2.456 & \\
\hline VEC Auto (1) & \multicolumn{2}{|c|}{12.16} & \multirow{2}{*}{\multicolumn{2}{|c|}{8.66}} & $02^{* *}$ & 15.68 & $17.45^{*}$ \\
\hline VEC Auto (2) & 6.51 & 8.71 & & & 13.31 & 10.54 & \\
\hline
\end{tabular}




\section{Appendix Table A2: Annual Models of the Small-Sized Loan Share of C\&I Loans \\ Long-Run Equilibrium: $S B S H_{\mathrm{t}}=\alpha_{0}+\alpha_{1}$ DFASB $_{\mathrm{t}}+\alpha_{2}$ Age2554 $_{\mathrm{t}} /$ WIRatio $_{\mathrm{t}}+\varepsilon_{\mathrm{t}}$}

Bank Asset Size Classes

All $\geq \$ 300$ Million

Model No.

Constant

$D F A S B_{\mathrm{t}}$

Age2554 (A models) $-2.6987^{* *}$

WIRatio (B models) (6.69)

unique coint.

vec. \# lags

trace no vec.

trace at least 1

trace at least 1
$2 \mathrm{C}$

0.2723

$-0.1064^{* *}$

$(18.22)$

Yes $^{* *}$
1
$55.55^{* *}$
$11.42^{* *}$
0.37

Large (top 12\%)

Small $(300 \mathrm{M} \leq$ assets $\leq \$ 1 \mathrm{~B})$

Short-Run: $\Delta S B S H_{t}=\beta_{0}+\beta_{1} E C_{t-1}+\sum \beta_{2 i} \Delta S B S H_{t-i}+\sum \beta_{3 i} \Delta D F A S B_{t-i}+\sum \beta_{4 i} \Delta P G D P /$ WIRatio $_{t-i}+\beta_{5} X_{t-}$ $1+\mu_{t}$

\begin{tabular}{|c|c|c|c|c|c|c|c|}
\hline $\begin{array}{l}E C_{\mathrm{t}-1,} \\
\text { 'adjustment speed' }\end{array}$ & $\begin{array}{l}-0.623^{* *} \\
(2.90)\end{array}$ & & $\begin{array}{l}-0.627^{* *} \\
(4.57)\end{array}$ & $\begin{array}{l}-0.928^{* *} \\
(7.92)\end{array}$ & $\begin{array}{l}-0.771^{* *} \\
(5.82)\end{array}$ & $\begin{array}{r}0.165 \\
(1.50)\end{array}$ & $\begin{array}{r}0.079 \\
(0.96)\end{array}$ \\
\hline$\Delta S B S H_{\mathrm{t}-1}$ & $\begin{array}{c}-0.011 \\
(0.06)\end{array}$ & & $\begin{array}{l}-0.184 \\
(1.27)\end{array}$ & $\begin{array}{r}0.0005 \\
(0.00)\end{array}$ & $\begin{array}{l}-0.204^{+} \\
(1.69)\end{array}$ & $\begin{array}{l}-0.081 \\
(0.32)\end{array}$ & $\begin{array}{l}0.299 \\
(0.14)\end{array}$ \\
\hline 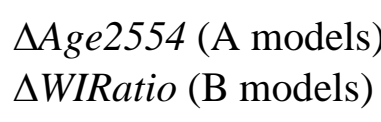 & $\begin{array}{l}0.559 \\
(0.94)\end{array}$ & & $\begin{array}{l}-0.025^{* *} \\
(3.20)\end{array}$ & $\begin{array}{l}0.249 \\
(0.74)\end{array}$ & $\begin{array}{l}-0.017^{*} \\
(2.63)\end{array}$ & $\begin{array}{l}-0.767 \\
(0.63)\end{array}$ & $\begin{array}{r}-0.061 \\
(0.34)\end{array}$ \\
\hline$\triangle D F A S B_{\mathrm{t}-1}$ & $\begin{array}{c}-0.042 \\
(1.53)\end{array}$ & & $\begin{array}{l}-0.037^{+} \\
(1.74)\end{array}$ & $\begin{array}{l}-0.044^{* *} \\
(2.80)\end{array}$ & $\begin{array}{l}-0.029 \\
(1.58)\end{array}$ & $\begin{array}{r}-0.053 \\
(1.37)\end{array}$ & $\begin{array}{l}-0.067 \\
(1.59)\end{array}$ \\
\hline$\Delta$ LiborSP $_{\mathrm{t}-1}$ & $\begin{array}{l}-0.027^{+} \\
(1.71)\end{array}$ & & $\begin{array}{l}-0.038^{* *} \\
(3.14)\end{array}$ & $\begin{array}{l}-0.030^{* *} \\
(3.87)\end{array}$ & $\begin{array}{l}-0.043^{* *} \\
(4.14)\end{array}$ & $\begin{array}{l}0.014 \\
(0.73)\end{array}$ & $\begin{array}{l}-0.010 \\
(0.45)\end{array}$ \\
\hline OutputGap ${ }_{t-1}$ & $\begin{array}{c}-0.0030 \\
(1.47)\end{array}$ & & $\begin{array}{l}-0.0080^{* *} \\
(4.36)\end{array}$ & $\begin{array}{c}-0.0063^{* *} \\
(5.53)\end{array}$ & $\begin{array}{c}-0.0053^{* *} \\
(4.11)\end{array}$ & $\begin{array}{r}0.0027 \\
(0.63)\end{array}$ & \\
\hline Constant & $\begin{array}{r}0.008 \\
(0.87)\end{array}$ & & $\begin{array}{l}0.006 \\
(0.93)\end{array}$ & $\begin{array}{l}0.005 \\
(1.12)\end{array}$ & $\begin{array}{l}0.011^{+} \\
(1.88)\end{array}$ & $\begin{array}{l}-0.012 \\
(-0.82)\end{array}$ & $\begin{array}{l}0.012 \\
(0.79)\end{array}$ \\
\hline Adj. $\mathrm{R}^{2}$ & 0.456 & & 0.690 & 0.854 & 0.761 & 0.055 & 0.002 \\
\hline S.E.x100 & 1.355 & & 1.023 & 0.672 & 0.847 & 2.170 & 2.230 \\
\hline $\begin{array}{l}\text { VEC Auto (1) } \\
\text { VEC Auto (2) }\end{array}$ & 13.88 & 16.79 & 4.30 & 05 12.69 & $\begin{array}{l}7.45 \\
\quad 3.22 \\
\end{array}$ & $\begin{array}{r}11.84 \\
3.34 \\
\end{array}$ & $\begin{array}{l}7.40 \\
\quad 5.61 \\
\end{array}$ \\
\hline
\end{tabular}

Estimated using data spanning 1993-2016 or 1993-2017. Notes: (i) Absolute t-statistics in parentheses. ${ }^{* *}{ }^{*}$ ): significant at the $99 \%$ (95\%) confidence level. (ii) Long-run: Maximum likelihood estimates of the long-run equilibrium relationship using a three-equation system with at most one cointegrating vector. (iii) Short-run: OLS estimates of speed of adjustment and short-run dynamics using the estimated equilibrium correction terms in (ii). (iv) First difference terms of elements in the long-run cointegrating vector after t-1 omitted to conserve space. (v) Lag lengths chosen to obtain unique significant vectors with sensible coefficients and clean residuals. (vi) The t1 output gap is omitted from the models including nominal per capita owing to collinearity issues. 